Vincenzo Bavoso'

\title{
Market-Based Finance, Debt and Systemic Risk: A Critique of the EU Capital Markets Union
}

\author{
${ }^{1}$ University of Manchester, School of Law, Manchester, United Kingdom of Great Britain and Northern Ireland, E-mail: \\ vincenzo.bavoso@manchester.ac.uk
}

\begin{abstract}
:
Modern, globalised financial markets are the offspring of a process of liberalisation of capital that started with the collapse of Bretton Woods in the 1970s and culminated with a number of regulatory changes in the 1980s and 1990s. As a consequence of that process, financial markets have grown dramatically and become increasingly integrated at a global level. Importantly, the growth and innovation that occurred over the past decade has taken place in the realm of capital market finance, and in particular in the context of market-based channels that revolved chiefly around securitisation and repo transactions. As a result, new debt transactions and products have been engineered since the 1980s.

This article contends that, contrary to conventional belief, the excessive development of market-based channels of finance has been one of the catalysts behind the crises and scandals exploded over the past fifteen years. In particular, the employment of innovative debt transactions was instrumental to the creation of excessive levels of risk-taking and leverage. These had catastrophic consequence, both at firm level and at systemic level.

Notwithstanding the regulatory measures that have been enacted over the past fifteen years, the way in which debt transactions in capital markets are designed and entered into remains lightly or indirectly regulated. Moreover, regulators have so far neglected the role that leverage and debt creation have in the economy and the consequence that these phenomena have on the wider social context. On the contrary, recently the EU has promoted the implementation of an old design, namely the Capital Markets Union (CMU). This revolves around market-based forms of financing, which should represent an alternative to the traditionally predominant (in Europe) bank-based financing channels. This article contends that the CMU framework fails to appreciate the dangers associated with capital markets finance and its ensuing debt creation effects. It argues that, despite some regulatory efforts, a suitable architecture for the regulation of market-based channels of finance is still missing.
\end{abstract}

Keywords: capital markets union, debt finance, market-based finance, leverage, leverage cycle, financial innovation, financial regulation, securitisation, repo

DOI: 10.1515/ael-2017-0039

\section{Table of Contents}

1 Introduction

2 Background

3 CMU in perspective

3.1 The key claims behind the expansion of market-based channels of finance

3.2 The CMU framework

4 The risks emerging from market-based finance

4.1 Highlighting problems of debt, leverage and liquidity

4.1 Market-based finance and leverage creation

4.3 Debt creation and the leverage cycle

5 The regulation of the securitised banking model under the CMU

Vincenzo Bavoso is the corresponding author

(c) 2018 Walter de Cruyter CmbH, Berlin/Boston.

This content is free. 
5.1 Securitisation under the EU capital markets union

5.2 Repo transactions under the SFT regulation

5.3 The new basel framework

6 Conclusion

References

"The trade of the petty usurer is hated with most reason:

it makes a profit from currency itself, instead of making it

from the process which currency was meant to serve.

Their common characteristic is obviously their sordid avarice." ${ }^{1}$

\section{Introduction}

This article is centred on a critique of the EU capital markets union (CMU). In particular, it presents the CMU within the broader context of expanding market-based channels of finance. ${ }^{2}$ It will be observed that the CMU is largely aligned with this trend (Financial Conduct Authority, 2016), and critically much of its action plan revolves around the development of debt capital markets, primarily securitisation and the bond market. Therefore, while this article is primarily concerned with the CMU and its attendant regulatory framework, the thrust of the critique here extends more generally to the problems associated with market-based channels of finance. Concerns arise for two main reasons. First, this article will explain how in the pre-crisis years the development of market-based channels of finance led to uncontrolled increases in leverage and risk-taking. These were caused by excessive private debt creation, which eventually contributed, among other things, to fuelling asset bubbles, and to the overall instability of the financial system.

The second reason for concern is related to the regulatory infrastructure that accompanies the implementation of the CMU. A number of regulatory failures were recognised in the aftermath of the 2008 global financial crisis, and importantly the post-crisis years also shed light on the segments of financial markets that were prone to instability. As the CMU aims to restart those very segments under a sustainable label (in particular securitisation with the STS Regulation as explained in Section 5), it is crucial to assess whether the relevant new regulations are adequate in addressing the problems that emerged in the pre-crisis years.

In order to answer these questions, this article traces in Section 2 the development of capital markets through the regulatory changes that led in the early 2000s to the emergence of the securitised banking model, whereby large financial institutions operated as dealer banks and engaged with wholesale funding channels (mainly securitisation and repo). This eventually characterised the way in which capital markets functioned in the years leading up to 2008. On the back of this analysis, Section 3 introduces the main claims behind the expansion of market-based channels of finance. This discussion provides the broader context for the analysis of the main pillars of the CMU, which revolves to a great degree around a revived securitisation market. Section 4 analyses market-based finance, pointing in particular to the risks that emerged in the pre-crisis years. Emphasis is laid on problems of leverage and the attendant instability that this creates on the financial system. As this part of the article argues that an expansion of market-based channels of finance is likely to re-propose problems of debt-creation and leverage, it is important to examine the regulatory framework that is in place to mitigate these risks. In order to do this, Section 5 focuses on the STS securitisation regulation, on the EU SFT regulation and the related FSB standards with respect to repo transactions, and it looks at the Basel III provisions covering leverage and liquidity. Section 6 concludes.

\section{Background}

Contemporary financial markets are the result of a process of transformation that can be traced back to the 1970s. A number of factors contributed, during that decade, to trigger drastic changes in politico-economic orientations (Gallino, 2011). These took place initially in the US and the UK - due to governments that were very receptive of the tenets of neoclassical economics - and slowly expanded worldwide through the influence of global regulatory networks, chiefly the IMF and the World Bank. The first relevant change was the collapse of Bretton Woods in the early 1970s due largely to the unilateral exit of the US. Bretton Woods had 
established a system of regulated fixed exchange rate and, more importantly for the purpose of this discussion, tight controls of cross-border financial flows. Capital controls were centrally regulated at national level and resulted in "closed" financial markets, where international manipulations of currency and securities markets became nearly impossible (Eichengreen, 2008, ch.4). Importantly, Bretton Woods coincided with a widespread acceptance of some of the tenets of Keynesian political economy, and in particular the importance of government intervention in financial regulation and supervision for the purpose of mitigating the impact of crises and shocks. Eventually, the end of Bretton Woods allowed foreign participation in other countries' capital markets. Moreover, the post-Bretton Woods architecture was grounded in supra-national organisations and free capital markets (Biondi, 2016; Eichengreen, 2008). This led among other things to macro-economic imbalances (Varoufakis, 2013) and to increasingly globalised and interconnected financial markets.

Policies and regulatory changes continued throughout the 1980s, until the late 1990s. They led to some far-reaching shifts, most importantly to the liberalisation of derivatives trading, chiefly through the abolition of distinctions between speculative and hedging transactions (Biondi, 2011; Stout, 2011). ${ }^{3}$ The consequential widespread employment of speculative derivatives went hand-in-hand with a process of financial innovation that, as will be discussed later in this article, achieved little economic value. Instead, it contributed to increasing risk-taking, leverage and complexity (Bavoso, 2016a; Schwarcz, 2009). Another prominent consequence of the regulatory changes during the above period was the abrogation of the prohibition to combine within the same financial institution commercial and investment activities. ${ }^{4}$ This led to a number of mergers and to the proliferation of larger institutions, whereby commercial banks could access the more profitable investment business (largely based on fees from underwriting, securities issuance or trading in financial products), while investment banks could benefit from the wider capital base of commercial banks. The resulting business model elicited a much greater level of risk-taking because the new universal banks could participate in risky and highly profitable capital markets activities (which as explained later in this article came to be known as securitised banking model), maintaining relatively low levels of equity capital (Avgouleas, 2010), while relying at the same time on government backstop in case of failure. As will be discussed later in this article, the profitability of this business model stemmed from high levels of leverage, which in turn guaranteed high returns for shareholders (see for an empirical analysis Biondi \& Graeff, 2017).

Regulatory changes also prompted drastic shifts in the capital composition of large financial institutions. Instead of funding their activities through more traditional deposit-based channels of finance (liabilities), they moved to wholesale forms of finance, centred on markets-based activities and products. It will be explained later that this brought about more complex and risky forms of maturity transformation and led banks to operate under higher levels of leverage (Cullen, 2017a).

From an institutional perspective, more general policies progressively transformed the role of the state in the regulation of the financial industry. ${ }^{5}$ This process was epitomised at a higher level by the privatisation of most utilities, public services and natural resources, which took place from the 1980s initially in the UK and the US (and is effectively still ongoing in most Western economies, with different nuances, due to persisting beliefs in the tenets of neoclassical economics). This orthodoxy prescribed a move away from state regulation which was deemed less efficient than market regulation in achieving regulatory goals. In the financial services industry this translated in the already signposted obliteration of capital controls and in the progressive reliance on market mechanisms (such as credit rating agencies for instance, or independent supervisory agencies at the EU level) to control and supervise the industry (Biondi, 2016; Moe, 2013). In hindsight, it has become evident that the move away from state regulation of certain aspects of financial markets has coincided with the progressive erosion of discipline in the industry (Coffee, 2009). Moreover, it is fair to say that failures of market discipline started to become apparent well before the global financial crisis (GFC) of 2008, possibly as early as in the mid-1980s with the Savings and Loan crisis in the US (Barth, 1991), then with the collapse of Long Term Capital Management in 1998 (Bookstaber, 2007, ch.6) and the ensuing meltdown of international financial markets.

Notwithstanding the process of financial integration and globalisation that went on from the 1980s, an international framework for the regulation of global financial markets remains today the greatest and most urgent policy challenge (Avgouleas, 2012). The erosion of a suitable regulatory infrastructure became more problematic given the concurring process of financialisation. This can be defined in different ways, but for the purpose of this discussion, it is the shift from industrial capitalism to financial capitalism, and the ensuing over-reliance of the economy on financial markets (Epstein 2005 provides a thorough investigation of the term financialisation; other relevant studies include Gallino, 2011; Krippner, 2005; Mitchell, 2010; Orhangazi, 2007). In particular, financialisation resulted in the greater reliance of both corporates and households on capital markets products instead of banking ones (G30, 2016, p. 6). The surge in capital markets activities contributed to the build-up of unprecedented levels of leverage, not only in the financial sector, but more broadly at the social level.

As an illustration, at the outset of the global collapse of 2008, private sector debt had soared in the UK from $50 \%$ in 1964 to $180 \%$ of GDP in 2007 (Turner, 2016, ch.3). ${ }^{6}$ It is trite to ask whether such a high rate of credit growth was necessary to facilitate a reasonable rate of economic growth and development (Turner, 
2016, ch.3). ${ }^{7}$ What is less contentious is that much of this excessive amount of privately created debt has been directed, particularly in the UK, to real estate lending (Turner, 2016, ch.4). ${ }^{8}$ As will be stressed later in this article, excessive debt and leverage are the primary causes of the disproportionate risk-taking and consequential instability that has characterised the last two decades. Increasing levels of debt are explained through the lens of capital markets development since the 1980s. Looking at the US for instance, while the level of equity issues has remained relatively stable since the mid-1990s, and it has not shown substantial growth, debt issues have skyrocketed (In 1996, debt issuances were about twice the size of equity ones. By 2014, they were five times their size. See Pragmatic Capitalism, 2015).

It further needs to be emphasised that the liberalisation of national financial markets contributed to their global integration. This was of course also due to the policies that allowed financial institutions to engage in the constant innovation of new products which in turn increased the interconnectedness between institutions and markets. Much of this innovation occurred in the realm of capital markets finance, and in particular in the context of debt finance, where long securitisation chains, combined with credit derivatives, caused a large scale homogenisation of financial institutions' balance sheets and their ensuing interdependence. It is important to also note that the process of financial innovation went on unconstrained and new transactions and products resulted in the creation of more debt system-wide.

While it is true that post-2008 this type of innovation may have slowed down, this process has remained loosely and indirectly regulated. This means that the role of leverage and debt creation (not only in the financial system but on the wider social context) that flows from these operations has been neglected by policy-makers until very recently. It is in connection with these regulatory concerns that the CMU is analysed in this article.

\section{CMU in perspective}

\subsection{The key claims behind the expansion of market-based channels of finance}

Modern financial markets result from the combination of two main channels of finance, traditionally identified as bank-based and capital markets-based. ${ }^{9}$ In theory the development of both channels provides an ideal combination of sources of finance that reflects the possibility for large borrowers to opt for bank-intermediated products or disintermediated market-based products. A balance between these two different financing mechanisms only exists in very few jurisdictions, most prominently in the US and in the UK. ${ }^{10}$ Due to historical, legal and institutional reasons, whose analysis is beyond the scope of this article, capital markets have developed in these countries to a much higher degree than in other developed economies (such as continental European ones or Japan), where the financial system still strongly relies on banks as the ultimate intermediator of finance (EU Commission, 2015b) ${ }^{11}$.

A number of studies, particularly post-2008, have laid great emphasis on the role that capital markets can play in the economy, particularly with respect to their function in facilitating capital raising and investing, risk management and price discovery (EU Commission, 2015b, p. 7). It is commonly argued that capital markets provide a vital financing source to economic activities by expanding the investor base beyond banks. This in turn allows a diversification of funding sources that enables borrowers to choose from competing sources and terms of financing. It is also contended that capital markets facilitate the efficiency with which available finance is allocated to the most productive projects, something that is often referred to as allocative efficiency. This contention is of course grounded upon the belief that through market mechanisms (such as arbitrage trading) the price of securities in capital markets responds immediately to price-sensitive information (Biondi, 2011). The efficiency discourse translates into the belief that capital markets provide an accurate valuation of a corporation and its assets. Much of the policies centred on the benefits of capital markets for economic growth is based on this efficiency assumption, which sees capital markets as the ideal platform for the quickest development of business ideas and entrepreneurial risk-taking activities (EU Commission, 2015b, p. 9; Anderson, Brooke, Hume, \& Kurtosiova, 2015; p. 4).

In the same vein it is argued that capital markets allow a more efficient distribution of risks than banks. An efficient market should in principle enable risks to be allocated to those who are better prepared to bear them and have the appetite for it. In turn, better risk allocation would increase the capacity of the financial system to extend more finance, in a way that does not have a detrimental impact on the economy or on the stability of the financial system.

Despite these theoretical claims, and some empirical evidence suggesting that the size of capital markets does lead to economic growth (Kaserer \& Rapp, 2014), ${ }^{12}$ the development of financial markets in the EU is characterised by an overwhelming reliance on bank-based channels of finance and on relatively under-developed capital markets. As an illustration, in the EU public equity markets represent $64 \%$ of GDP whereas in the US 
they represent $138 \%$ of GDP; debt securities are $12.9 \%$ of GDP in the EU, against $40.7 \%$ in the US (EU Commission, 2015b, p. 11). A comparison with the US shows also that the market values of equity, corporate bonds and securitisation across the EU represent respectively $60 \%, 35 \%$ and $20 \%$ of the US counterpart (Anderson et al., 2015, p. 6). From a different perspective, bank lending amounts to $32 \%$ of private sector credit in the US (against $20 \%$ being represented by corporate bonds, $32 \%$ by asset-backed securitisation, $16 \%$ by non-bank loans), whereas the same cumulative figures for UK, Germany, France, Spain and the Netherlands show bank lending amounting for $68 \%$ of private sector credit (against $10 \%$ of corporate bonds, $8 \%$ of securitisation, $14 \%$ of non-bank loans) (G30, 2016,p. 6).

\subsection{The CMU framework}

Some of the goals and motivations underpinning the EU Capital Markets Union reflect the more general claims illustrated in the previous section, pertaining to the qualities of market-based channels of finance and to the economic development that can be attained thanks to disintermediated financing channels. Policy discourse also takes into account some issues that are more specifically related to EU financial markets and the way in which they reacted to the 2008 crisis.

In the Commission papers it is generally acknowledged that the size and development of capital markets does not necessarily entail economic benefits and that this can depend on a number of institutional and regulatory preconditions. It is also admitted that much of the growth in debt capital markets activities in pre-crisis years was effectively not aimed at supporting any real economy activity and resulted instead on profits being kept within the financial system. The growth of market-based channels of finance, such as securitisation, also brought about increased interconnectedness between markets and institutions and higher risks of contagion and systemic risks (EU Commission, 2015b, p. 12). These concerns are also reflected in recent findings. The Bank for International Settlements recently looked at the effects of financial sector growth on the real economy and concluded that the growth of the financial system, at certain stages and levels of economic development, can result in a drag on productivity growth. This means that financial booms are not always accompanied by growth and development in the real economy, also because the financial sector tends to compete with other sectors of the economy for resources. BIS also critically stressed that credit and financial booms tend to cause greater harms to sensitive areas of the economy, particularly those revolving around innovation, research and development (Cecchetti \& Kharroubi, 2015). In a study focused on emerging economies, the IMF also stressed that beyond a certain level of financial development, the benefits initially experienced in the economy begin to decline while costs associated with financial volatility rise and extend to the real economy, causing instability. The IMF emphasised that financial development entails trade-offs and that risks of financial instability can be mitigated by building strong institutions and a sound regulatory and supervisory framework (IMF, 2015).

Bearing in mind the above overarching concerns related to the further integration and development of European capital markets, the Commission in its Green Paper (Building a Capital Markets Union) proposed a number of arguments that are critically illustrated in this section. Firstly, arguments related to diversification of sources of finance and the optimal allocation of funds across the EU (EU Commission, 2015a, p. 4) have been used to support the contention that the banking sector across the EU was over-burdened in the years preceding the global financial crisis. The Green Paper essentially reiterated that the over-reliance on the banking sector was the determining factor that impaired the quality of European banks' balance sheet. This in turn led, especially post-2008, to their limited lending capacity and higher costs of funding. It is also observed by the Commission that the story was different in the US, where the more diversified financial system, as outlined in the previous section, allowed tapping other sources of finance, mostly market-based ones (Anderson et al., 2015; p. 7; for a critique on this stance see Wray, 2013).

For the purpose of understanding the context of the $\mathrm{CMU}$, and eventually the risks related to it, a different side of the above story needs to also be told. The Commission's analysis fails to consider the changes in business model that affected European banks in the decades before 2008. The deregulation of financial services propelled the proliferation of large megabanks which started to progressively engage with risky market-based activities, instead of the more traditional lending ones. Banks' balance sheet was particularly affected by this trend because instead of funding their activities through deposits (as it was traditionally the case), banks started to rely increasingly on wholesale market-based funding channels, represented primarily by repo transactions and securitisation. As will be discussed in closer details later in this article, this funding pattern became particularly problematic due to the magnified maturity mismatch ${ }^{13}$ and the higher risks that banks became exposed to (Avgouleas, 2010; Biondi, 2016). The result of European banks' increasing interaction with market-based activities was a sharp increase in the way they contributed to systemic risk (Yongoua Tchikanda, 2016). It could thus be fair to argue that the underlying shift in banks' funding patterns is arguably what impaired their lending capacity once the credit crunch unfolded in 2007 and the market for short-term lending between financial institutions froze. Other explanations however need to also be taken into account to understand the problems experienced 
by European banks in the post-crisis years. Southern European banks in particular were affected by a severe sovereign debt crisis that further impeded their capacity to support the real economy (see Blundell-Wignall, 2011, who highlights among the causes of the underlying problems in Europe, the absence of a growth strategy, high levels of sovereign corporate and household debt, too large banks that became involved with dangerous capital markets trends). Some of these problems will be further expounded in part D of this article.

The Green Paper stressed that banks could not adequately support demands for finance after the GFC, and that this in turn worsened the economic crisis. This assessment also fails to draw a fundamental distinction between large universal banks in the EU and smaller cooperative banks that operate in some European regions. In a report published in 2016, the German Bundesbank revealed that domestic business loans represent $8 \%$ of total assets for big banks, while they are $28 \%$ of total assets for cooperative banks (Deutsche Bundesbank, 2017). Similarly, data from the Bundesbank have demystified the belief that all banks after the crisis stopped supporting the economy by lending to business. Again, German cooperative banks increased their lending to businesses between 2008 and 2011 by 14 \% (Deutsche Bundesbank Eurosystem, 2017; Hasan, Jackowicz, Kowalewski, \& Kozlowski, 2014). ${ }^{14}$ Conversely, it has also been observed that banks that are heavily engaged with capital markets activities, both on their assets and liabilities side, are less prone to lending to business (Abbassi, Iyer, Peydro, \& Tous, 2016, who explain that banks that invest in securities through proprietary trading reduce the credit supply to the real economy).

As a final note on this, it should be acknowledged that not all economic analyses agree with the Commission's approach to explain post-crisis recession. It has been strongly argued that the protracted economic crisis is not actually caused by a lack of bank lending to enterprises, but rather by the austerity measures enacted post-crisis, which have in turn had the consequence of killing consumer demand, and therefore business' need for credit (Varoufakis, 2013).

The second strong claim made by the Commission in the Green Paper, which has also become one of the flagships of the CMU project, is that market-based channels of finance would be instrumental to improving access to finance for small and medium-sized enterprises (SMEs) across Europe (EU Commission, 2015a, p. 9). This is grounded on the idea that the type of private sector risk-sharing platform represented by capital markets would provide much needed sources of funding to SMEs and at the same time it would allocate resources optimally across EU businesses. This has raised some criticism, leading some commentators to counterclaim that SME finance is not a realistic goal and that the Commission was only using it to brand the CMU project (Elliott, 2015). ${ }^{15}$

Much of the critique relates to the huge information costs that are associated with small, often local businesses throughout the EU (Schammo, 2017). The assessment of their credit and liquidity would be difficult to make in capital markets and it is likely that investors would have to take high (and perhaps uncalculated) risks to fund SMEs' projects. Conversely, banks are traditionally better positioned to fund SMEs due to their preferential access to relevant data and to their ability to know local businesses. Beyond representing a more efficient allocation of financial resources, banks seem to be better at serving the interest of SMEs in EU countries (Hasan et al., 2014 who confirmed that SMEs perform better in countries with large number of cooperative banks). As a final point of critique, it needs to be remembered that capital markets across the EU remain highly fragmented along national borders (EU Commission, 2015b, p. 11-13), due chiefly to different legal frameworks (as regards private law, insolvency law, labour law) and also cultural factors. While it is likely that large multinational corporations and financial institutions could reap the benefits of pan-European capital markets, it is very difficult to envisage SMEs as beneficiaries of the CMU project. ${ }^{16}$

An overarching critique of the CMU project is that from its inception with the Green Paper, and down to the action plan and current implementation steps, there has been a strong emphasis on the need to resuscitate the securitisation market. Other avenues to develop equity-based channels of finance, like for instance equity crowdfunding, have remained tentative or have been lagging behind (EU Commission, 2017). The emphasis on securitisation and corporate bonds under the CMU would inevitably result in a further increase in the level of leverage in the EU financial sector and eventually at the social level too, represented, as already pointed out by Turner, by excessive levels of real estate lending. The Commission seems to be aware of this dangerous trend as it has reflected on the prevalence of corporate bond issues over corporate equity issues. While this distortion is traditionally ascribed to general bias and particularly tax policies, it remains a problematic source of private debt creation (largely through market-based channels) which increases the fragility of the financial system as a whole (EU Commission, 2017, p. 10; FCA, 2016). 


\section{The risks emerging from market-based finance}

\subsection{Highlighting problems of debt, leverage and liquidity}

As was illustrated in Section 3 of this article, the project to implement a capital markets union is grounded to a great degree on the further development of market-based instruments. These, following the definition provided by the EU Commission, would result in the creation of more debt products, and / or in the strengthening of debt capital markets. In particular, the Commission referred to (1) debt and equity markets; (2) derivatives markets; (3) securitisation and structured finance markets (EU Commission, 2015b, p. 5). This trend would be consistent with the direction that financial development and financial innovation have taken over the last two decades, whereby it was believed that financial innovation - and in particular a higher degree of financial intermediation - would overall achieve the goal of completing and diversifying markets, providing better capital allocation, thereby creating more stable financial systems (Segoviano, Jones, Lindner, \& Blankenheim, 2015).

Criticism of the above patterns of financial development follows the already illustrated questions of excessive debt creation and the ensuing boom-and-bust cycles that are discussed later in this article. The problem with debt markets and the creation of excessive amounts of debt is also to be found in the intrinsically private nature of most debt contracts and in the way in which in modern liberalised financial markets banks operate and extend credit. Banks (and even more problematically shadow banks as will be discussed later in this arti$\mathrm{cle}^{17}$ ) in most instances do not intermediate already existing money - which in textbook examples should be allocated from savers to investors - but instead create new money. A recent paper by the Bank of England has demystified the process of money creation, by clarifying that commercial banks create the majority of money in the economy as they make loans. This means that money is not actually intermediated by banks, from depositors to lenders, but it is actually created ex novo with new loans. It follows that loans create deposits and not vice versa (Hockett \& Omarova, 2017; McLeay, Radla, \& Thomas, 2014). This counters the assumptions of fractional reserve banking, whereby central banks control private banks' money supply through reserves, namely the percentage of deposits that is needed to create new loans (Avgouleas, 2016; Ricks, 2011) ${ }^{18}$. The Bank of England instead explains that money creation is constrained by the central bank chiefly through interest rates (McLeay, Radla, \& Thomas, 2014). Under either explanations, money creation is associated anyway with new debt in the economy.

As has been observed by Turner, the credit created by banks is in most cases not directed at supporting new business investments, but more consumption or the purchase of already existing assets (with real estate being a classic example) (Turner, 2016, introduction). The reason for this trend has to be found in the private self-interest (as opposed to welfare-enhancing, which could be the case for instance of cooperative or mutual banks) that characterises banking activities. In modern financial systems most banks are private institutions and their business strategies are driven pre-eminently by shareholders' appetite to reap returns (return-onequity or RoE) (Avgouleas, 2010, pp. 22-24, pointing in particular to the homogenisation of trade behaviour on the part of large banks). As it is well known though, shareholders', as well as executives', incentives are distorted by a number of cultural and psychological factors (Avgouleas \& Cullen, 2015) but most importantly by their limited liability. This allows taking up more risks because they are protected against the downside of bad investments, while they will benefit from any upside. Excessive levels of risk-taking were also the result of perverse incentives with which the board and top executives were compensated (Avgouleas \& Cullen, 2015).

As will be illustrated later in this article, psychological and behavioural factors also play an important role in the way in which banks (or rather those who take investment decisions in banks) allocate their resources because this will depend on how they perceive the state of the world at any given time. As their expectations are optimistic in fact, they will allocate resources to riskier investments, while after a round of bad news materialise they will invest in safer projects trying at the same time to decrease their level of leverage (Bhattacharya, Goodhart, Tsomocos, \& Vardoulakis, 2011). While this bias clearly hinders optimal welfare investments (Avgouleas \& Cullen, 2015) a further problem is that these investment patterns are highly pro-cyclical and in fact accelerate the leverage cycle (Avgouleas \& Cullen, 2015; Bhattacharya et al., 2011).

The capacity of banks to create new credit becomes particularly problematic for two main reasons, namely because of the intrinsically high leverage under which they operate, and because of the long and complex chains of transactions that they originate in the capital markets, what is referred to as securitised banking model. These transactions in particular seem to be at the heart of the plan to revive EU capital markets, since securitisation features as the central pillar of CMU. It has been widely observed that securitisation-type transactions in the precrisis years were conducive to increasing levels of risk-taking, higher levels of leverage, and interconnectedness with the shadow banking system. Overall, securitisation did not contribute in the pre-crisis years to a more efficient allocation of financial resources, but it rather represented a way for financial institutions to extract rents from other financial intermediaries, mainly those at the end of the long and opaque transaction chains (Bavoso, 2017; Gorton, 2007; Turner, 2009). 
While it appears incontrovertible that modern developed capital markets lead in most cases to an increase of debt in both the financial system and in society, policy-making in the post-crisis years has not come to terms with this fundamental problem, which in fact remains neglected by mainstream economics (that has remained myopically focused on the control of inflation) (Turner, 2016). The excessive credit creation of the past decade is in fact a consequence of the nature of bank contracts and the way in which banks operate; this in turn has resulted in the instability that, as will be discussed in the next section, is the natural outcome of any system that is allowed to create private credit under limited or no control. ${ }^{19}$

The question that regulators have failed to address in the pre-crisis years (and to a great degree they still fail to do so) is that banks profit from operating with a high level of leverage and, if this specific aspect of their operations is not adequately regulated, they will do so by lengthening the intermediation chain through the shadow banking sector, thereby contributing to the creation of endless supply of credit (Blair, 2013). While it is clear that leverage increases returns for shareholders, policy-makers have for too long ignored the detrimental effects that this can have on the financial system as a whole, and also on other stakeholders, like creditors, consumers or taxpayers. The expansion of credit supply increases debt and leverage, ${ }^{20}$ which may be profitable for the individual firm (as it leads to a quicker and cheaper asset growth), but will inevitably result in excesses of credit and eventually asset bubbles (Blair, 2013). From a policy perspective, it is worth noting that asset price bubbles represent a distortion in the allocation of capital in the economy as well as the distribution of wealth. This is so because, as asset prices increase due to the credit cycle (analysed in the next section), market participants will tend to feed the credit cycle by supplying more credit on one side and taking it on the other. As suggested by Blair, portfolios of investments rise in value largely because of leverage-driven asset inflation (Blair, 2013, pp. 434-438), something that has become particularly relevant in the context of the housing market in both the UK and the US, and that affects financial assets generally.

Regulating private credit creation has been particularly problematic from the 1980s onward, because financial institutions started to engage with shadow banking activities, both on their assets and liabilities side, increasing therefore interlinks with what were at that time unregulated entities and products. Firms operating in the shadow banking system replicate, to some extent, functions that are typical of credit intermediations, without however being bound by the relevant regulatory framework that applies to banks. This refers to a number of areas, among which, reserve requirements and capital requirements. Reserve requirements relate to the amount (or rather the percentage) of cash reserves that banks receive as deposits and that should be set aside and deposited with the central bank. ${ }^{21}$ This is central to the idea of fractional reserve banking and money multiplier that in textbook treatises are represented as mechanisms that should limit the amount of money created by banks. ${ }^{22}$ The ability of banks to "create" money is however not limited to the money multiplier or to other regulatory constraints - because financial innovation has allowed crafting ways in which assets can be hold without holding cash, and more generally because various forms of credit function that are alternative to money have been introduced in the financial system (Blair, 2013, p. 430). One such form is represented by repo transactions, a typical feature of the shadow banking sector, which performs a critical function in providing short-term liquidity to banks as a form of near-money effectively (Cullen, 2017b; Ricks, 2011) ${ }^{23}$. Even though central banks have maintained a residual control over the amount of money in circulation in the economy, the private sector has progressively gained a much greater role in the creation of near-money assets and generally in the creation of credit (Positive Money (Biondi \& Zhou, 2017, 2017) ${ }^{24}$.

Capital requirements are traditionally aimed at limiting the level of risk-taking that banking institutions can engage with, by imposing a cushion against losses from money claims. This cushion is normally represented by the percentage of equity that banks have to hold against certain assets, and the amount of the cushion varies according to the riskiness of the assets. The function of capital requirements includes absorption of bank losses, limit of risk-taking, and a market monitor (Cranston, Avgouleas, Van Zwieten, Hare, \& Van Sante, 2017, ch.2). In essence, well-functioning capital requirements limit the level of leverage that banks can operate with.

This area of banking regulation has been highly affected by financial innovation. In particular, the development of the shadow banking system and the securitised banking model allowed banks to access an almost unlimited supply of credit, by originating in other words assets beyond the limits of capital requirements. Much of the securitised banking system took place outside the umbrella of banking regulation. This is a problem because an effective control of the relationship between debts and assets (or in other words the desired ratio between bank's capital and debt) is what could limit the amount of credit created by banks and also their level of leverage (Blair, 2013, p. 433). The application of capital requirements has traditionally been a complex area of banking regulation, and it is centred since the late 1980s on the Basel accords (I, II and III).

As it was stressed in the previous section, the increase of leverage in the financial system is what led in the pre-crisis years to unprecedented levels of instability, simply because the existing tools aimed at measuring and controlling leverage were either not adequate or were being bypassed. It is also worth remembering that within financial institutions leverage is instrumental to profitability, because it maximises returns on equity for shareholders and allows management to earn from compensations ${ }^{25}$ (bonuses and stock options) (Avgouleas 
\& Cullen, 2015). It is however often noted that while financial institutions in the pre-crisis years kept reaping huge profits by overleveraging (so even with a small return in total assets), the picture seemed different as the increasing levels of leverage were not always apparent (Kalemli-Ozcan, Sorensen, \& Yesiltas, 2011 ${ }^{26}$ ). This was the result of the way in which financial innovation and regulatory loopholes (mainly within the Basel framework) allowed banks to move assets and liabilities outside the regulatory perimeter, often in the shadow banking system, thereby creating a hidden level of leverage (Simkovic, 2009; p. 256; Thiemann, 2012). While this increased dramatically the riskiness and vulnerability of certain individual banks, it also affected the safety of the financial ecosystem as a whole, what is referred to as the macro-prudential or systemic effect of leverage. As it turned out in fact, while the Basel framework was mainly directed at monitoring individual institutions in a micro-prudential fashion, the effects of leverage became truly systemic due to the highly contagious assets held by most banks and due to interconnectedness between regulated financial institutions and the shadow banking sector (Haldane \& May, 2011).

The problem that seems to remain currently unsolved, and partly ignored by policy-makers, is that financial institutions are still likely to engage in strategies that aim to expand their asset base through a number of capital markets transactions. This is at the heart of the criticism against the EU CMU, which has not taken under due consideration the unintended consequences of their policy options (Bavoso, 2016b). While it is possible that the CMU could create new financing channels to the real economy, it has also been observed that if credit expands in the financial sector faster than the real economy, as it has happened in the last two decades (Turner, 2016, ch.1), this excess of credit will contribute to increasing the price of existing assets, which in turn will lead to asset bubbles (Blair, 2013, p. 441).

The above proposition is consistent with what Minsky postulated in the 1970s. He argued that under certain economic conditions, banks engage in asset growth strategies. They do so by resorting to financial innovation, which facilitates portfolio transformation that effectively decreases bank liquidity while increasing its leverage. Minsky argued that inflations of asset prices would be a likely consequence of these strategies (Minsky, 1970, pp. 13-14). It is important at this stage of the discussion to note that bank leverage was justified in the precrisis years because of the increase in market discipline that it would bring about (this was due of course to the undisputed reliance on neoclassical assumptions of market discipline ${ }^{27}$ ), and by the resulting liquidity creation. Liquidity refers to two main aspects in financial markets, namely funding liquidity and asset liquidity. The former involves the maturity transformation function that is typical of the banking business, whereby banks originate long-term illiquid assets and fund them through short-term liquid debts (Cullen, 2017a; Ricks, 2011; p. 85). Asset liquidity reflects the types of assets that banks decide to invest in, and their ability to convert them into cash at short notice. It is trite to point out that assets of low quality are normally illiquid and when converted into cash they are sold at a discount. This means that in times of stress (like the post-2008 turbulence) the sale of such assets results in "firesales", which have the effect of worsening liquidity problems at the systemic level, as banks hold similar and contagious assets (Cullen, 2017a).

Notwithstanding the importance of liquidity in banks' balance sheet, banks with high levels of leverage engaged before 2008 in lending practices that were too risky and, among other things, led to problems of illiquidity (this will become clearer in the next section). These business models exposed the weaknesses of the financial system because liquidity shocks suffered by an individual financial institution would affect other firms too. Acharya and Thakor point in this sense to the "schizophrenic role of leverage", which provides on the one hand banks individually with better asset choice and more liquidity, but on the other hand propagates fragility in the financial system. This leads ultimately to a friction between the role that leverage and liquidity creation have ex ante, and the systemic risk that they create ex post (Acharya \& Thakor, 2017). Arguably, regulators are yet to come to terms with this. Policy-makers in particular are faced with the intractable dilemma of looking at the right balance between the ideal level of leverage that is optimal for individual financial institutions vis-à-vis the socially desirable level of leverage that is likely to be much lower (for a discussion, Wagner, 2011).

\subsection{Market-based finance and leverage creation}

In order to understand the link between capital markets finance, increases in overall levels of leverage, and instability, it is necessary to reconceptualise the operational framework of market-based finance and how financial institutions interplay in this system. From the 1970s, on the back of the large scale deregulation of financial services, capital markets (also referred to as market-based) channels of finance started developing and expanding. Within this evolving context, banks as well as other non-bank financial intermediators started offering banking-like products. This became particularly relevant with respect to maturity and liquidity transformation, and risk sharing mechanisms. As progressively more traditional banking institutions started to engage with capital markets activities (what Hockett \& Omarova, 2017, define as the "functional integration of banking and capital markets"), their business model changed dramatically and most importantly their balance 
sheet shifted from a deposit-based model to a wholesale funding model (for an illustration see Von der Becke \& Sornette, 2017, p. 8).

As this model of credit intermediation evolved, incorporating capital markets activities, large banks started operating as dealer banks, purchasing portfolios of bonds from the capital markets, and funding them by issuing money-market instruments (Mehrling, Pozsar, Sweeney, \& Neilson, 2013; Ricks 2011, p. 85). To understand how this business model works, it is useful to look at the contextual evolution of banks' balance sheet. It is also important to observe that dealer banks were at the centre of intermediation chains involving non-bank entities in the shadow banking system. In the pre-crisis years these revolved around securitisation and repo transactions (Pozsar, Adrian, Ashcroft, \& Boesky, 2010 p. 10). In particular, on the assets side, ${ }^{28}$ instead of more traditional mortgage or loan exposures, dealer banks started having long-term asset-backed securities (Pozsar et al., 2010 p. 10-11). ${ }^{29}$ The different set of risks attached to these securities were sold off to other intermediaries in capital markets (normally asset managers) via a number of derivatives contracts, such as interest rate swaps, foreign exchange swaps, or credit default swaps. These risks were then sold by asset managers, who as derivatives dealers were seeking to create a market for these risks and sell them to investors (FCA, 2016, p. 13). The effect of this process was that dealer banks were holding assets perceived as risk free (and therefore highly liquid). It is precisely these so-called risk-free assets that banks were using as collateral in order to access funding in the money market (FCA, 2016 and 2011; p. 84).

The extensive interaction with wholesale funding enabled banks to extend their lending capacity and grow their balance sheet beyond their core liabilities. Credit intermediation in the wholesale system allowed banks to access large sources of funding whereby the only constraint to their capacity to borrow was represented by the quantity and quality of collateral that they could post. Much of this collateral came in the form of securitised assets, either manufactured by the same bank or purchased from other banks (Finance Watch, 2014, pp. 3839). It is well known that to increase lending, banks should increase their regulatory capital, or reduce existing risks. Both of these strategies though would be detrimental to the overall profitability of banks, particularly with respect to their return on equity. More and cheaper lending instead is enabled through the wholesale market, where, as discussed later in this section, the only constraint on the assets used as collateral is the haircut (in essence the risk attributed to the assets pledged) (Finance Watch, 2014).

Through the above system, dealer banks became in the pre-crisis years strongly interconnected with wholesale markets on their liabilities side, ${ }^{30}$ as they relied chiefly on short-term money market funds to finance their operations. This model of banking intermediation has been aptly defined as "money market funding of capital market lending" (Mehrling et al., 2013; Pozsar, 2014 p. 40). Even more effective is the labelling of the evolved business of banks as securitised banking, which refers to the predominant pre-crisis practice that saw large banking conglomerates packaging and reselling loans on their assets side, while repo transactions were the main source of funds on the liabilities side (Gorton \& Metrick, 2012). This model is centred on the application of securitisation, which allows the origination of many assets (hundreds of mortgages together for instance). These assets were then transferred to a special purpose vehicle (SPV), which in turn issued debt securities backed by the asset pool to investors in the capital markets. This practice allowed banks to remove the loan inventory from the balance sheet, enabling therefore the origination of more loans and asset expansion generally. Under the securitised banking model, banks thus profited from loan intermediation rather than from the origination and holding of loans on balance sheet (Gorton \& Metrick, 2012, p. 434). The funding model prevalent in this system therefore was characterised by the increase in stock of securitised bonds that in turn facilitated forms of financing based on collateral, such as repo transactions and securities lending (Cetorelli, 2014, p. 4, arguing that this model led to the growing centrality of dealer banks and the market for securities lending and repo agreements). This represented in the pre-crisis years a further incentive for large banks to issue as many securitised bonds as possible, and to borrow money to buy other entities' securities (Varoufakis, 2013, p. 8).

During the years before 2008 the extensive employment of wholesale funding channels contributed to the accumulation of high levels of leverage and to a general understatement of risks which banks could not withstand. It also became a critical engine behind the increase of interconnectedness and systemic risk because banks were purchasing each other's securities with borrowed money, which further increased leverage and the concentration of risks in systemic institutions (Moe, 2015, p. 8). As will be explained later in this section, this intermediation channel eventually triggered liquidity crises (and in particular, as explained in the previous section, funding liquidity), chiefly due to the reliance on short-term assets to fund long-term liabilities, and the inability, once bad news materialised, to renew short-term funding channels (Gorton \& Metrick, 2012; p. 426; Wray, 2013; pp. 293-294). Eventually credit intermediation through the shadow banking sector (securitisation and repo) replicated some of the problems traditionally associated with the regulated banking sector, namely maturity transformation and leverage, but they were magnified by the lack of transparency and regulation in the shadow banking sector and also by the opaqueness of transaction chains therein (Turner, 2016; p. 4; Ricks, 2011). 
An important aspect of the securitised banking model is that the bonds issued by the SPV are layered in tranches with different seniority and subordination, whereby the first losses on the underlying pool are borne by the bottom (equity) tranche of the bond, while the top senior tranches are the most secure, and therefore rated AAA. ${ }^{31}$ As will be further illustrated later in this section, securitisation tranches, especially the more senior ones, became highly employed in capital markets, both as collateral, in repo transactions or in loans provided by the central bank, and as assets in other securitisations. ${ }^{32}$ The demand for safe and liquid assets, and the contextual shortage of low-risk government bonds, which traditionally epitomise low-risk collateral, made securitised tranches highly instrumental to the functioning of market-based finance.

Repurchase agreements (referred to as repo) in particular became a central mechanism of liquidity in the evolved market-based financial system. Repos typically refer to transactions where one party (say a bank) borrows short-term funds from another party (say a money market fund) by transferring the legal ownership (Gabor \& Ban, 2016 explain that the economic ownership is not also transferred because the borrower remains risk-bearer for the assets used as collateral) of a certain asset, the collateral, to the lender (that in turns engages in a reverse repo). Contextually, the borrower promises to repurchase the asset at a later date. In the event of a default by the borrower and its incapacity to return the cash, the lender can sell the collateral. Two mechanisms protect the lender from losses, namely the repo rate and haircuts. A haircut implies that the lender demands collateral whose market value is higher than the value of the loan, ${ }^{33}$ and similarly margin calls are used when the collateral falls in value, in order to ensure that the repo is fully collateralised.

Two legal features made repo agreements particularly advantageous in the market-based financial system. Firstly, the transfer of the collateral to the lender allows its immediate access to the securities in case of borrower's default (Cullen, 2017b, p. 7). Secondly, the transfer of ownership entails that lenders can dispose of the collateral and in particular they can re-use it as collateral in other similar transactions (what is referred to as rehypothecation). It is also useful to draw the distinction between bilateral repos, which function on a "delivery-versus-payment" basis and where cash and collateral are exchanged simultaneously, and tri-party repos, where the parties use an agency to manage the transaction and check the suitability and the eligibility of the collateral (Cullen, 2017b, p. 6).

Despite warning signs that the repo market could represent a source of uncertainty in financial markets and a channel for the uncontrolled increase in leverage, its development remained unfettered. This policy direction stemmed from the conviction that an active repo market could ensure the liquidity of government bond markets and that in order to have a well-functioning and liquid market, this should remain virtually unregulated, relying instead on mechanisms of self-discipline and on risk management regimes based on initial haircuts on collateral (Gabor, 2016, p. 981). By the late 1990s all European repo markets had been liberalised. Most critically, at EU level this was seen as the fulcrum of the European monetary order based on the single currency, and also the engine behind the much desired shift towards market-based finance where large European banks would increasingly fund their positions in securities markets through the repo market (Gabor, 2016; IMF, 2014; Shirrell, 1999). In the words of EU policy-makers, the evolving market-based financial system was to be preferred due to its efficiency, regardless of the question of stability. It was thought that financial stability could be supplemented by a liquid and transparent government debt market, where the free movement of collateral and liquidity across member states would guarantee financial stability (and at the same time facilitate the process of financial integration) (Gabor, 2016, p. 983). Moreover, policy-makers seemed to identify financial stability in market-based financial systems with unfettered liquidity. Hence, the idea that highly-liquid assets should be at the heart of a repo market in order to guarantee access to funding channels in periods of market stress (Bank of International Settlements, 1999).

Eventually, the repo market grew exponentially in the post-liberalisation years due to the increasing amount of cash held by a number of entities, among which institutional investors, pension funds, mutual funds, and also states and government entities, all seeking safe investments with a good return on deposit and the flexibility to use the deposited cash and cash-equivalents (Gorton \& Metrick, 2012, p. 435 $5^{34}$ ). Moreover, the market progressively included among the accepted collateral private ABSs and securities issued by shadow banking entities. Due to the scarcity of government securities, deemed safe, the process of manufacturing high-quality collateral through financial innovation (securitisation) was encouraged, particularly by the Fed and then by its EU counterpart. ${ }^{35}$

The illustrated evolution of the securitised banking model needs to also be seen as the functional integration of banking and capital markets. Hockett and Omarova (2017, p. 1175) explain that this integration, associated with the expansion of shadow banking, facilitates replicating modes of credit creation that are traditionally prerogative of banks, ${ }^{36}$ and that in fact result in the replication and amplification of bank lending. ${ }^{37}$ Of course, this functional integration was possible because of the institutional integration, in turn facilitated by the regulatory changes highlighted in part B of this article. ${ }^{38}$ This angle of analysis is important because it explains some of the motives behind the process of financialisation, discussed earlier. It provides a clearer link between the changes in the banking system expounded in this section and the attendant effects on financialisation. In particular, 
the work conducted by Hockett and Omarova (2017, pp. 1211-1213) highlights the critical institutional design (under what they call the finance franchise) that gave way to a dysfunctional ${ }^{39}$ interaction between the financial system and the real economy, which eventually manifested with excesses of credit creation. Importantly for the purpose of this analysis, this failure is recognised also as a regulatory one, and specifically as a failure to correctly modulate and allocate credit, something that becomes relevant in connection with the analysis conducted in part $\mathrm{E}$ of this article. ${ }^{40}$

After 2008, the risks associated with the securitised banking model became more evident. Gorton and Metrick stressed that the global financial crisis affected mostly dealer banks that had been active in the repo market, while commercial banks had actually grown their balance sheet chiefly through deposits, so when the crisis hit, their position was stronger (Gorton \& Metrick, 2012, p. 433; Wray, 2013). Gorton and Metrick illustrate this problem by looking at Lehman's downfall in 2008, noting that like other investment banks, it was funding around half of its assets using short-term repo transactions. The opacity of the repo market, which was unregulated and relied on self-discipline mechanisms, meant that confidence and trust were critical among repo counterparties - due also to what Hockett and Omarova term in their analysis as regulator absenteeism (p. 1212). As confidence was lost in Lehman's ability to repay (and also on the quality of the collateral it posted), repo counterparties declined to roll-over daily funding and that made Lehman unable to operate ${ }^{41}$ (Gorton \& Metrick, 2012).

The increasing concern in the post-crisis years is that instead of supporting liquidity in financial markets, market-based financial systems centred on securitisation and repo agreements are actually less liquid and lead to accumulation of leverage. While the leverage cycle and the way in which financial institutions interplay with it will be discussed in the next section, it is worth further exploring at this stage the feedback effect between market-based finance and leverage. As stated earlier, the securitised banking model allowed dealer banks to increase their asset base while maximising the use of their capital base. This trend however was accompanied by a progressive decrease in liquidity in the banks' balance sheet. Loutskina shows that the ability of banks to securitise their loan portfolios coincided with a decrease of liquid assets on their balance sheet. Her study observed that increases in the liquidity of banks' loan portfolio of $1 \%$, coincided with a decrease of around $23 \%$ of the level of on-balance sheet liquidity (Loutskina, 2011, p. 665). This phenomenon was more apparent within US investment banks, where increasingly securitisation allowed removing assets from the balance sheet, therefore freeing regulatory space for the origination of more assets without any contextual increase in capital (on-balance sheet liquidity) (Loutskina, 2011). Securitisation in other words appears to have caused the decrease in balance sheet liquidity in the pre-2008 years and a contextual increase in the level of leverage and risk-taking that dealer banks were operating under. Moreover in the securitised banking model, as explained, assets on banks' balance sheet were used as collateral in repo agreements in order to borrow short-term, which made dealer banks more vulnerable.

The above analysis leads to the conclusion that the market-based securitised banking model that was prevalent before 2008 led to an amplification of liquidity risks in the financial system. This was allowed by the combined use of securitisation and repos and in particular by the way in which banks were reusing collateral to back several securities (Geanakoplos \& Zame, 2010). As explained by Cullen, rehypothecation in repo agreements was facilitated by the legal characterisation of the transfer of asset, where title to the security passes to the lender at the beginning of the repo agreement and remains with the lender until the debt is repaid. The lender therefore can use (rehypothecate) the same security as collateral to fund new borrowing with the consequence that the same asset is effectively used to collateralise a chain of loans, and the creation of collateral can be infinite (Cullen, 2017b, p. 13, where it is emphasised that the use of multiple repos through rehypothecation highly increases the level of leverage). As explained by Gorton and Metrick, the collateral becomes a form of money multiplier and a mechanism that increases interconnectedness and correlation between different institutions' balance sheet as well as an engine for the accumulation of hidden leverage in the shadow banking system (Gorton \& Metrick, 2012; p. 430; EU Commission 2014; p. 117).

\subsection{Debt creation and the leverage cycle}

This paper argues that the EU policy and regulatory agenda enshrined in the CMU is likely to accelerate a leverage cycle, which in turn could lead to a situation of instability similar to what is hypothesised by Minsky. This section illustrates the possible feedback loop between the current EU policy and a further increase of leverage in the financial system. The contextual illustration of the leverage cycle provided in this section is relevant not only to understand the events of 2007-08, but more importantly to evaluate the possible risks flowing from the proposed implementation of the EU CMU. This will become more evident in the next section, which critically illustrates the regulatory approach endorsed by the EU to control the two main arms of a resurgent securitised banking model, namely the securitisation market and the repo market. Beyond the question of whether the CMU represents an enabling regulatory framework (conducive therefore to a return to pre-crisis structures 
and operations), it is important to realise that there is already a tangible return to pre-crisis levels of optimism that are characterising financial markets globally. ${ }^{42}$

Geanakoplos defines leverage as the ratio of asset value to the amount of cash that is needed to purchase that same asset. In the example of a house, where the house costs $£ 100$ and it is purchased with $£ 20$ cash and $£ 80$ of borrowed money, the leverage ratio is represented by $100 / 20=5$, which is the reciprocal of margin in fact (Geanakoplos, 2010). From a different perspective, at the entity level, leverage can also be represented by the use of borrowed money relative to equity. Leverage has been recognised as a path dependence process in relation to financial stability. This is due to the way in which banks affect the leverage cycle through investment decisions and portfolio problems they face in specific periods.

During good states of the economy, characterised by optimism, banks are willing to take more risks (invest in riskier projects/assets) and at the same time creditors are willing to extend finance more easily, despite the increase in riskiness (Bhattacharya et al., 2011, p. 4). Both phenomena are related to the determination of borrowing rates and credit spread. Bhattacharya et al. explain that low credit spreads allow banks to borrow more, which will in turn increase their level of risk-taking and therefore also the credit spread (Bhattacharya et al., 2011, pp. 4-5). Since expectations and optimism can build up in good times (despite the prospect of penalties due to defaults), riskier projects become more attractive to financial institutions, because the expectation of penalty for default decreases due to optimism. Creditors therefore are willing to offer low borrowing rates notwithstanding the riskier projects that debtors have invested in (Geanakoplos, 2010b, p. 103). ${ }^{43}$ This dynamic allows financial institutions to increase their leverage and also the possibility of default due to the underlying risky assets / projects. When a bad state realises then, financial instability will ensue (Bhattacharya et al., 2011, pp. 4-5). This general description is well reflected in the structure of financial markets and in the behaviour of large financial institutions in the pre-crisis years. The securitised banking model for instance allowed banks to securitise large amounts of loans, remove them from their balance sheet and thus free regulatory capital to originate greater volumes of credit. The ensuing increase in leverage was disguised by the opacity of the underlying processes (securitisation chains and repo transactions) and by the over-optimism of market participants (Galbraith, 1994) until 2007, when the run on Northern Rock unveiled the bad state and the ensuing instability of the financial system.

Geanakoplos notes that the leverage cycle is a self-reinforcing dynamic. The increase in leverage (and the coincidental decline in margins ${ }^{44}$ ) is the consequence of good news and the perception that there are no dangers in the economy. As already explained, optimism drives lenders to become less cautious, and to provide more credit while reducing margins. This availability of relatively cheap credit leads in turn to increases in the level of borrowing, which is the prime source of asset prices inflation (Geanakoplos, 2010b, p. 104). At this stage, due to the high riskiness of the underlying assets/projects, loss-given defaults ${ }^{45}$ may start kicking in, and bad news materialise. As economic prospects deteriorate, the level of leverage starts going down as higher interest rates are charged. A fall in asset price ensues and this process is further worsened in the event of a contextual increase of margins (Geanakoplos, 2010b, p. 104; Bhattacharya et al., 2011); p. 15. Once asset prices fall, banks shift their investment patterns and only choose safe projects/assets, in order to balance the cost of leverage (Bhattacharya et al., 2011, p. 5). The cycle is even more problematic when an increase in margins accompanies bad news. Beyond the very highly leveraged buyers (the more optimistic ones), who are forced to sell their assets when asset prices go down, also modestly leveraged buyers are forced to sell when margins tighten in more substantial measure. This in essence is what drives prices further down and leads to the worst stage of the crisis, a fire-sale, the cause of which is further expounded below (Geanakoplos, 2010b, p. 105).

In the scenario portrayed in the previous section, with dealer banks engaged in the securitised banking model, the increase in margins can have disastrous effects. If margins were to increase for example fifty percent overnight, ${ }^{46}$ banks exposed to the repo market on their liabilities side would have to double the amount of cash held against the same assets, or else sell the assets, often at very low prices, which would effectively results in massive deleveraging. As observed earlier in this article, Gorton and Metrick provided the same explanation to understand the freezing of credit markets in 2007, which was eventually the consequence of a run on the repo market (Fostel \& Geanakoplos, 2013; Gorton \& Metrick, 2012). In Geanakoplos' illustration of the leverage cycle, the sequence of events that occurred in 2008 is also the result of irrational reactions and panic among market actors that ensue the emergence of the cycle, which in turn cause prices to go further down. This is followed by bankruptcies among the most leveraged institutions, and the complete dry-up of the lending market (Geanakoplos, 2010b, p. 106). It is again necessary to point out that irrational reactions and panic were the consequence of the breakdown of the market mechanisms designed to safeguard the stability of the securitised banking model. This proved to be grounded on highly pro-cyclical dynamics (epitomised by the volatility of margins in the run-up to the crisis) and on the failure of the market discipline approach to regulate these segments of financial markets.

In the context of the analysis proposed in this article, the problems that emerged in 2007 need to also be understood, within the leverage cycle, as a crisis of the assets that were being pledged as collateral. This was 
particularly the case with the triple-A CDO tranches that were considered safe assets in the repo market. Before 2007 these assets were in high demand as collateral in repurchase agreements and banks could borrow $90 \%$ on the value of these assets. ${ }^{47}$ After 2007, and following the run on the repo mentioned in the previous section, the value of these assets became uncertain and banks could no longer rely on them to access channels of liquidity. In the context of the 2007-08 crisis, it is important to understand that the cycle was magnified by the impact that financial innovation had on collateral and therefore on margin requirements. Transactional innovation and in particular the shift from plain vanilla securitisation to synthetic CDOs - facilitated the creation of new private securities that could be used as collateral in the repo market. The problem experienced in the pre-crisis years was that even if margin levels remained the same on old collateral, the process of securitising assets (and importantly, as was the case with CDOs, the securitisation of already existing debt securities, already used as collateral, and disguised through a new tranched security) would allow new borrowing backed by what effectively were individually unusable assets (Geanakoplos, 2010b, p. 112). ${ }^{48}$ This in turn further increased the overall level of leverage in the economy.

Financial innovation unleashed another engine within the leverage cycle, namely credit default swaps (CDS). These insurance-like derivatives allowed pessimist feelings - that surfaced when bad news materialised - to be magnified. This was possible due to the nature of CDSs, which allow taking asymmetric bets on the collapse of underlying assets, because the potential loss for the protection buyer is limited while the gain triggered by the event of default is virtually unlimited (Lewis, 2010). The practice of betting against a declining market - or what careful insiders perceive as being declining - contributes to further increasing the level of leverage at the worst stage of the leverage cycle, namely when pessimism takes over and asset prices plummet (Geanakoplos, 2010b, p. 113).

The mechanics of the leverage cycle are complemented by the financial instability hypothesis (FIH) formulated by Minsky, which offers further insights into the different stages of instability that lead to a crisis (Minsky, 1992; 1977; 1980). ${ }^{49}$ Minsky viewed instability as an intrinsic and endogenous character of financial systems, especially when financial development revolves around more complex forms of intermediation and innovation (Minsky, 1992; 1980). Within these financialised systems, periods of euphoria tend to lead to speculative excesses, fuelled by financial innovation and high levels of leverage, which in turn lead to distortions in the value of assets. It is a central contention in this article, as will be explained in the next section, that regulation can also fuel a period of speculative excesses by enabling and facilitating certain practices (Bavoso, 2016b). ${ }^{50}$ This cycle represents of course a severe threat to systemic stability (Minsky, 1980, p. 517, 1970; p. 6). Moreover, in line with what was said earlier, Minsky argued that the behaviour of financial institutions is an engine of instability, due to the uncertainty (and pro-cyclicality) of their investment patterns, and it is the vehicle that transmits instability from the financial system to the real economy (Minsky, 1992). Instability is specifically the result of banks' interplay with financial transactions that facilitate the creation of more debt during periods of euphoria (Minsky, 1970, pp. 10-13).

The degree to (and speed with) which this euphoric phase can lead to a crisis depends, according to Minsky, on the type of financial unit used by market actors, and more importantly on the proportion of a certain type of unit across the economy. Financial units can be classified as hedge, when they are asset-based and the cashflow expected from the assets meet future payments (both principal and interest). These units remain stable notwithstanding macro-economic changes (Minsky, 1992). Financial units defined as speculative do not only rely on asset-based cash-flow, but on refinancing their position through debt contracts, such as securitisation for instance. In essence, as these units cannot repay the principal out of their cash-flow, they need to continuously refinance and roll-over their liabilities. These units are therefore vulnerable to deteriorating market conditions (Minsky, 1992). Units defined as Ponzi do not generate sufficient cash-flow to meet repayments on interest or principal and are therefore forced to either borrow more (which further increases their leverage), or sell their assets, under the expectation that asset prices keep increasing (Minsky, 1982, p. 22; Biondi 2013). These investment units are of course the most sensitive during the cycle once margins tighten and asset prices plummet (Minsky, 1992). The predominance of one of these three investment patterns in the financial system determines the intensity of the boom period, the degree to which credit arrangements can be managed and the stability of the system as a whole (Minsky, 1992; 1970, pp. 45-51; Cullen, 2014; ch.4).

The essence of Minsky's hypothesis is that instability and crises in the financial sector are endemic as well as inevitable. This is particularly the case in financialised economies, such as the US and the UK, shaped over the past three decades by the creation of uncontrolled level of private debt (Turner, 2016) through market-based processes. Financial crises are followed by collapses in the value of assets and disruptions to other areas of the economy. This article contends that the $\mathrm{CMU}$, and the attendant regulatory agenda, are likely to lead to an increased level of financialisation in Europe and to more unstable financial markets. To assess and corroborate this, it is necessary in the next section to analyse the regulatory infrastructure that is in place at the EU level and its prospect of preventing, under the CMU framework, the recurring of a cycle as it was hypothesised in this section. 


\section{The regulation of the securitised banking model under the CMU}

The account provided in Section 3 and 4 of this article shows that securitisation and the repo market were in the pre-crisis years the engines of the Anglo-American type of financial capitalism, both being at the heart of the securitised banking model analysed earlier in this article. This description however does not reflect how financial markets work at present, because after 2008 the securitisation market has been moribund (especially in the EU, and to some extent in the US too) (Bavoso, 2016b), and equally the volume of repo transactions has been reduced (FCA, 2016). The limited capacity of EU financial markets (and generally of modern globalised financial markets) to function under current market constraints (Bavoso, 2016b) provides a valuable perspective to appreciate the EU plan aimed at developing market-based channels of finance (Gabor, 2016).

Given the strong policy drive to expand market-based channels of finance, in spite of the risks experienced in the run up to 2008, it is interesting to reflect on the proposed EU regulatory infrastructure, and appraise whether this is likely to prevent or mitigate the occurrence of a leverage cycle, and of ensuing financial instability. In a recent study, the IMF concluded that financial development involves both benefits and costs, which are related to financial instability. These risks, the IMF observed, can be mitigated through sound regulation and strong institutions and supervisory structures (IMF, 2015). This is in line with what is suggested by Geanakoplos in the context of the leverage cycle, that due to the dynamic of the cycle and the way in which market-actors interplay with it, government intervention is needed. This arguably is the case regardless of whether banks act rationally, because it is precisely their rationality that drives the cycle, in a "tragedy of commons" fashion (Hardin, 1968). ${ }^{51}$ When market-players act irrationally (as it is the case during fire-sales for instance), the consequences of a crisis can be more severe, and the role of regulatory intervention becomes even more relevant (Geanakoplos, 2010b p. 117). This echoes the observation by Bhattacharya et al, who point out that, at different stages of the cycle, market-players act on the basis of incomplete information (Bhattacharya et al., 2011, p. 27 where it is observed that agents have incomplete information about the real world probability of a good state occurring and, as Bayesian learners, they try to infer it by observing past realisations).

The rest of this section focuses on a critical examination of the regulatory framework under which the CMU would function. The analysis is centred on the Securitisation Regulation (also referred to as Simple Transparent and Standardised Securitisation (STS) under the CMU, on the reform of repo transactions under the EU Securities Financing Transactions Regulation, and on the relevant reforms within Basel III that are aimed at tackling problems of liquidity and leverage.

\subsection{Securitisation under the EU capital markets union}

A project to revive the securitisation market in Europe has been ongoing since at least 2014, when the Bank of England and the European Central Bank kick-started a debate on how to develop securitisation in the EU. This led to the EU Proposal for a Regulation on Securitisation, also labelled STS, which was adopted in December 2017 (Regulation EU 2017/2402).

Regulatory efforts have sought to firstly, define sustainable ${ }^{52}$ high-quality securitisation that would achieve the beneficial functions of the transaction while reducing asymmetry of information and excessive risk-taking, and secondly, design a regulatory regime for products that comply with the definition and are thus attached a different risk calibration. The proposal therefore revolves around the creation of a label (the STS), whereby transactions that comply with the requirements of simplicity, transparency and standardisation, would receive a better prudential treatment. Overall, the requirements seek to make risks easier to assess for investors through standardised disclosure and transparency processes (EU STS Consultation, 2015, p. 7). The idea of simplicity promoted by the Commission is also instrumental to the aimed alignment of interests between investors and originators of securitised products. ${ }^{53}$ More specifically, as regards the three criteria, simplicity requires the underlying exposures to be homogeneous and it prohibits re-securitisations, ${ }^{54}$ and restricts the use of derivatives for hedging purposes only ${ }^{55}$; transparency requires compliance with transparency and disclosure requirements ${ }^{56}$; standardisation requires the transfer of assets to the SPV to be a true sale, ${ }^{57}$ which means that synthetic transactions ${ }^{58}$ fall outside the umbrella of STS (EU STS Consultation, 2015, p. 7).

While a more detailed analysis of the STS regulation has been conducted elsewhere (Bavoso, 2016b), the question here is to determine the extent to which the Regulation will foster a stable securitisation market. One initial reflection in this respect relates to the system designed to verify compliance with the STS criteria. Interestingly, the Commission opted for a private notification process (EU STS Regulation, art.14) ${ }^{59}$ instead of a public certification system. This, in other words, empowers originators and sponsors in securitisation transactions to ensure compliance with the STS label and leaves investors to exercise due diligence before buying securitised bonds. The process is not however complemented by a robust and harmonised supervisory framework because the EU supervisor (European Securities and Markets Authority, ESMA ${ }^{60}$ ) is only attributed a coordination role 
under the regulation, while national authorities are tasked with the monitoring of market developments and imposing sanctions (EU STS Consultation, 2015, p. 8; EU STS Regulation, Art.29).

ESMA is neither empowered in standardisation efforts, because the Commission preferred to leave this in the hands of industry associations (EU STS Consultation, 2015, p. 8). The Commission's approach in this respect raises doubts, due to the limited ability of market-players to recognise systemic risks and in particular to identify the systemic effects of their actions. These concerns are also rooted in the definition of simplicity under the STS Regulation, which may leave market actors with too much freedom to manoeuvre and innovate. Concerns stem from two specific lacunae in the proposal. First, the Commission has completely failed to elaborate on the problems related to tranching, which remains a practice accepted under the regulation. In the pre-crisis years tranching allowed banks to originate assets of poorer quality, which would receive triple-A rating due to the complex correlation formulae underpinning the bundling process, the credit enhancement mechanisms, and of course the way in which assets were sliced and repackaged under different risk and return. Moreover, combined with the use of CDSs, entered by banks to hedge certain exposures or to speculate on certain assets, tranching led to homogeneity between banks' asset portfolios, or in other words a high degree of correlation between their balance sheets. High correlation in turn led to interconnectedness, heightened systemic risks and contagion between different tranche-holders (Bavoso, 2016b; p. 17; Finance Watch, 2014; p. 35). Against these concerns, it needs to be said that the STS Regulation does put in place a number of safeguards, namely the limitations on asset types, the prohibition of re-securitisation, as well as the ban (for the time being) of synthetics (see for an interesting perspective Schwarcz, 2016, p. $135^{61}$ ). All in all though, the increased complexity flowing from tranching is at odds with the overarching aims of simplicity and transparency.

The second lacuna in the proposal is the ambivalence towards synthetic transactions. Under the Regulation synthetics fall outside the perimeter of the STS label (Art.20 STS Regulation). This stance however is subject to a further distinction (based on a report produced by the European Banking Authority) between different types of synthetics, namely balance sheet synthetic transactions, ${ }^{62}$ and arbitrage synthetic transactions ${ }^{63}$ (EU Parliament Briefing, 2016; European Banking Authority, 2015). The prohibition in the STS Regulation concerns arbitrage synthetics (specifically Art.8 (9a)), whereas with respect to balance sheet synthetics, the Parliament has mandated the Commission to draft a legislative proposal aimed at extending the STS framework to these transactions. Again, a framework in this sense will be based on criteria determined by EBA (EU Parliament Briefing, 2018). This development comes as a result of strong pressure from market participants, and especially banking lobbies, that insisted that despite the risks associated with synthetic transactions, they are often the only efficient way to securitise risky assets, such as SMEs' loans (Bavoso, 2016b; EU STS Consultation, 2015, p. 15). It is worth remembering that synthetic CDOs became, due to their peculiar legal structure, extremely popular between 2000 and 2007 as they allowed the transfer of risk of more assets than under traditional securitisation and also the securitisation of assets with a less predictable cash-flow (Bavoso, 2017, p. 373). The chief drawback of these structures was the much greater level of leverage they created, together with the increased correlation of banks' balance sheet (Bavoso, 2017).

The regulatory agenda set out by the Commission is identified in this article as a wider problem affecting the way in which the STS Regulation is implemented, and more broadly the institutional framework of the CMU. The Commission Green Paper stressed that market-driven solution would be preferred and that regulatory changes would only be considered if necessary. The existence of ESMA (and of ESAs more generally) of course means that on paper the Commission's stance is correct and that there is no need to establish a new panEuropean authority to supervise capital markets. Questions on the effective powers of ESMA however have been raised, especially due to the budgetary constraints under which it operates and the relevant supervisory powers that it has not so far exercised (Lannoo, 2015, p. 6; Schammo, 2011). The Commission has not clarified this point in the various CMU consultation documents and doubts therefore remain on the capacity of ESMA to adequately face the task of supervising fully integrated EU capital markets. On the contrary, the notification system embedded in the STS Regulation and the role attributed within it to market actors and residually to national authorities show that the CMU is likely to develop in a regulatory landscape permeated by the belief in market discipline. This is highly reminiscent of the laissez-faire environment that led to the abuses of capital markets finance in the pre-crisis period and to uncontrolled increases of leverage.

In line with the critique expounded earlier in this section, on the role of government institutions in preventing and managing different phases of the leverage cycle, it is difficult to envisage how the CMU project can deliver the announced goals and benefit the real economy, without the steering function that is typically associated with government institutions. The risk with the present framework is that it confers too much power to market actors and in particular to the large dealer banks that are the more likely beneficiaries of the CMU. Their actions (and their truncated rationality driven primarily by maximisation of returns on equity) are likely to lead to an expansion of market-based practices (securitisation for instance and potentially departures from the STS label as explained above) and to an increase of leverage in the financial system as was experienced in the pre-crisis period. 
While the institutional structure of the CMU is relevant also in the context of the SFT Regulation and Basel III (both discussed below), it is worth stressing here the importance that a strong supervisory body has for the successful implementation of the CMU as a whole. Throughout this article, reference to the role of ESMA was made several times and doubts were raised as to its capacity to oversee the integration of EU capital markets. Admittedly, supervisory integration in this area has remained limited ${ }^{64}$ with national authorities still playing a central part in the supervision and enforcement of the single rulebook (Sapir, Veron, \& Wolff, 2018, p. 7). While a full discussion on the role of ESMA and its institutional structure is beyond the scope of this article, it helps remembering that ESMA's current design reflects that of a collective actor, rather than a fully-fledged supervisory authority (in this sense Schammo, 2011). Like the other ESAs, ESMA's current more realistic capacity is to assist the Commission in preparing technical rules and performing supervisory coordination (Sapir, Veron, \& Wolff, 2018, p. 8).

Notwithstanding these limitations, it is correct to infer that the success of the CMU plan - and more specifically of the economic goals at the heart of it - rests on a sound supervisory structure grounded on the revisited powers and role of ESMA. This contention echoes the already cited assertions in this article, ${ }^{65}$ suggesting that wholesale capital markets should be overseen by a public regulator, equipped with adequate binding force, and thus able to enforce supervisory convergence across the EU (Sapir, Veron, \& Wolff, 2018, p. 9). ${ }^{66}$

\subsection{Repo transactions under the SFT regulation}

Section 4 of this article highlighted some of the problems that emerged in the context of the securitised banking model and in particular it laid some emphasis on the importance of the repo market. Despite being strongly interlinked with securitisation, there is little or no reference of repo transactions in the CMU framework, and how they ought to be regulated. The Commission did neither clarify in the STS regulation the linkages between securitisation and the shadow banking system and the level of leverage transmitted between the two. Admittedly, the EU paid little attention to the repo market - referred to as securities financing transactions - in the pre-crisis period, despite it being much larger than the securitisation market (Gabor \& Vestergaard, 2015, p. 3).

This regulatory void was partly filled with the enactment in 2015 of the Securities Financing Transactions Regulation in the EU (EU Regulation, 2015/2365). This was primarily aimed at reducing risks and increasing transparency in repo-type transactions. The Regulation is grounded on two main strategies. The first one is represented by limits on the reuse of financial instruments received as collateral by the transaction counterparties. These are subject in particular under article 15 of the Regulation to two conditions: 1) the providing counterparty has been informed by the receiving counterparty of the risks and consequences related to either granting a right of use of collateral, or concluding a title transfer collateral arrangement; 2) the providing counterparty has granted prior express consent to a security collateral arrangement which enables a right to use, or it has agreed to provide collateral by way of title transfer collateral arrangement (EU Regulation, 2015/2365, art.15(1) $a$ and $b$ ).

The second strategy is represented by reporting requirements embedded in articles 4 and 13 of the Regulation. Article 4 sets the general terms of the reporting obligations that counterparties in SFTs have to comply with, and together with the necessary formalities, it highlights the role of trade repositories and the coordination role of ESMA for their registration (EU Regulation, 2015/2365, art.4 (4)(5); art.5). Article 13 sets details of the disclosure requirements of UCITS management and investment companies as well as AIFMs to their investors, as regards the use they make of SFTs.

From this overview it appears that the Regulation is focused on the disclosure of information provided to counterparties in repo transactions. While this is certainly a step in the right direction to tackle problems of counterparty credit risk and systemic risk, it is also appropriate to critique the effectiveness of these provisions for two reasons. The first one relates to the Regulation's assumption that counterparties act rationally if provided with adequate information. As discussed earlier in this paper in the specific context of the leverage cycle, and as evidenced by the behaviour of financial institutions in the pre-crisis years, this assumption is rather illusory. Moreover, counterparties in the repo market tend to be individually rational in seeking short-term profits, while the collective welfare of the financial system is beyond this dimension of rationality, representing, again, a tragedy of commons situation. The question of collateral reuse is very much one of systemic importance, because it is the chain of rehypothecations, rather than the individual one, that increases leverage and impairs financial stability. The second concern relates to the supervision and enforcement of the Regulation's provisions, which will essentially depend on member states implementing relevant regimes through their national authorities, with ESMA, again, playing merely a coordination role.

From a different angle, the question of minimum requirements for haircuts has been left out of the SFT Regulation. The Commission acknowledged in the Regulation's preamble that sound regulation of haircuts in repo transaction would prevent excessive leverage and concentration of risk among financial institutions, but this task was left to the Financial Stability Board (FSB) through a framework for SFT haircuts. The FSB 
published in 2015 a Regulatory Framework for Haircuts on Non-centrally Cleared SFTs in order to establish a globally applicable regime for haircuts on non-cleared transactions, among which repos (FSB, 2015).

The FSB framework is centred on two main provisions, namely, (a) incorporating qualitative factors into new or existing methodologies used by repo counterparties to calculate haircuts; (b) applying de minimis throughthe-cycle haircut floors to non-centrally-cleared repos, where financing against collateral, other than government securities, is provided to non-bank entities. Crucially, this framework excludes from its application (a) centrally-cleared SFTs provided to banks and broker-dealers subject to adequate capital and liquidity regulation; and (b) repo transactions carried out by central banks (FSB, 2015).

The first element of the FSB framework aims to limit the potential pro-cyclical fluctuations in haircuts. It seeks to limit the capacity of haircut to contribute to financial instability through the dynamics of margins in the leverage cycle, which was described earlier in this paper (FSB, 2015, p. 5). The second element of the framework is designed to set limits on the amount that non-banking entities can borrow against different types of securities in repo transactions. This provision should serve to limit increases in leverage outside the regulated banking system and at the same time reduce the pro-cyclicality of leverage (FSB, 2015, p. 7). With respect to the haircut floors within this provision, they vary according to the category of the security pledged, its market risk and historical performance. They range between $0.5 \%$ applied to short-term corporate debt, $6 \%$ for main index equities, and to higher haircuts for securitised debt, and $10 \%$ applied to other assets within the scope of the framework (FSB, 2015, p. 8). Critically, so called "collateral upgrades" 67 are also covered within the floors (FSB, 2015, p. 10).

The FSB's recommendations on minimum haircuts will rely on market participants establishing internal processes and procedures in accordance with the framework, while the monitoring of margin requirements will be coordinated by the relevant regulators together with the Basel Committee and IOSCO (FSB, 2015).

Finally, it needs to be remembered that in tri-party repo transactions the collateral cannot be rehypothecated outside the tri-party venue. This entails that the management of these repos through an agent bank can provide regulators with information that would not be available in bilateral repos. This contention is substantiated by empirical evidence on the stability of tri-party repos during the GFC (Copeland, Martin, \& Walker, 2011). Much of the repo market however, is characterised by bilateral transactions, especially in Europe where they amount to $70 \%$, while in the US they are between one-third and half of the market (Cullen, 2017b, p. 19). Regulators, as a consequence, have chosen central clearing counterparties (CCP) to manage repo transactions and to provide the market with the necessary level of transparency. At the EU level, this already happened for derivative transactions under EMIR (European Market Infrastructure Regulation) (2012), and in the repo market CCPs will perform the role of intermediaries, guaranteeing the transaction's performance in the event of counterparty failure. In essence, counterparty credit risk is transferred to CCPs that in turn are protected by taking collateral from each counterparty in the repo and by collecting a default fund from its members, for losses that exceeds the transaction's margins.

It seems clear that the initiatives to regulate haircuts should mitigate risks related to the pro-cyclicality of margin valuations, especially in periods of market stress. Moreover, more complex securities, such as securitised bonds, will be under higher margin requirements and this should provide the market with a better degree of stability and predictability. The limits on rehypothecation too are likely to reduce leverage and volatility in the financial system (Cullen, 2017b, p. 21).

Doubts however remain on the effectiveness of these measures. It was argued earlier in this article that in order to monitor leverage in the securitised banking system, there should be policies in place that create a sufficient level of transparency of haircuts among the entities operating in the shadow banking system, and of course adequate haircuts in the repo market. This article contends, like a number of other academic works have done (Constancio, 2016; Ricks, 2016), that more direct and intrusive regulation of the repo market is needed in order to achieve the level of financial stability that is desired by the EU Commission. This argument is based on two main problems, already identified earlier, namely the loose institutional structure of EU capital markets regulation, where ESMA does not seem in the foreseeable future to be attributed the powers (and funding) that are necessary to supervise pan-EU capital markets. Secondly, the overarching regulatory technique permeating this area of capital markets, still revolving around disclosure mechanisms and market discipline assumptions.

\subsection{The new basel framework}

Despite being outside the CMU umbrella, the Basel III framework introduces a number of provisions that can potentially tackle problems of leverage and liquidity, highlighted in the earlier discussion on the dangers flowing from the securitised banking model. The new Basel package introduced a wide array of relevant provisions, including macro-prudential tools and corporate governance requirements. For the purpose of this discussion, attention is drawn here to capital requirements, leverage ratio, and liquidity requirements under Basel III, bearing in mind that these will be effective by January 2019. 
Firstly, Basel III introduced higher capital requirements, ${ }^{68}$ implemented in the EU through the fourth Capital Requirement Directive (CRD IV) ${ }^{69}$ It also created two specific capital buffers, a capital conservation buffer and a countercyclical buffer. Capital conservation buffers require banks to hold an extra $2.5 \%$ of tier- 1 capital, which is designed to ensure that banks build up capital buffers outside periods of stress, in an effort to limit the pro-cyclicality of capital requirements (BCBS, 2011, para 54). These are particularly aimed at constraining arbitrary distribution of earnings, such as dividends, share buy-backs, and bonus payments, which had become common prior and during the crisis years. Countercyclical buffers represent a macro-prudential approach to capital requirements as they focus on the aggregate credit growth that a country is manifesting. ${ }^{70}$

The Leverage Ratio (LR) introduced with Basel III will cap the total amount of leverage that banks can achieve and will require banks with a large share of high risk-weighted assets to have additional loss-absorbing capacity. Importantly, the LR is a non-risk-based capital measure, ${ }^{71}$ defined as tier-1 capital over a bank's total exposures, including also off-balance sheet ones (BCBS, 2014). It is expected that this will increase the resilience of large banks as it will provide a measure to contain aggregate risks and a protection against losses in the financial system that is not part of the risk-based capital framework. Moreover, the LR is designed to contain regulatory arbitrage and curb the capacity of banks to leverage their capital base (Cranston et al., 2017, p. 53). The risk insensitivity of LR though means that assets with the same nominal value but different riskiness are treated equally and face the same capital requirement under the LR. It has been observed in this respect that the move away from risk-based capital may allow banks with low risk-weighted assets to increase their risktaking beyond a desirable level, offsetting therefore the benefit of holding more capital under the LR (Grill, Lang, \& Smith, 2015). Ultimately, the LR requirements will not work in isolation and will have to be judged in the broader context of the overall prudential framework under which financial institutions operate.

Similarly, the liquidity reforms embedded as part of the Basel III Accord, namely the Liquidity Coverage Ratio (LCR) and the Net Stable Funding Ratio (NSFR), are conceived to improve the ability of banks to absorb shocks arising from financial stress and reduce the possibility of spill-overs from the financial system to the real economy (BCBS, 2011 and 2017a). The LCR requires banks to maintain a minimum amount of high-quality liquid assets for the purpose of surviving a 30-day stress scenario, during which the stock of high-quality liquid assets must remain at least $100 \%$ of the bank's total net cash outflows. Importantly, the definition of high-liquid assets favours government bonds, while disfavours clearly market-based products, such as ABS (Basel Committee on Banking Supervision 2013, para 17). The NSFR requires banks to preserve a percentage of available stable funding (ASF, such as deposits, or equity, and excluding short-term wholesale funding) for the amount of required stable funding (RSF, determined on the basis of the bank's activities, its maturities, asset liquidities and sources of funding) (Basel Committee on Banking Supervision, 2014, para 4-9-17). The NSFR have the clear aim of limiting banks' exposure to short-term funding, and this is designed to restrict as a whole the excessive interdependence with the shadow banking system (and particularly with wholesale funding) that existed before 2008.

While these measures represent clear improvements from the pre-2008 regulatory environment, their effectiveness relies on the overall liquidity of the financial system. This in turn is closely linked to the general availability of collateral, especially for short-term borrowing. The demand for safe assets as collateral however, is contrasted with a general and long-standing scarcity of collateral, which is expected to increase in the foreseeable future, according to BIS estimates (Bank of International Settlements, 2013).

The above remark is linked to the critique of the STS framework, conducted earlier in part E. One of the objectives of a revived securitisation market is precisely the re-establishment of a private system of collateral creation, which would grease short-term wholesale markets and therefore the market-based dimension of the financial system. This article expounded a number of concerns related to the way in which the STS framework is implemented. These pertain to the incomplete definition of what simple securitisation should be and at a higher level to the regulatory and institutional arrangements surrounding the STS securitisations. Therefore, if general conditions of liquidity do improve in the financial system, due to the introduction of more collateral, it would be legitimate to question the real quality of the underlying assets pledged as collateral (Bavoso, 2016b). Doubts in this sense are pertinent because under Basel III, STS securitisations will receive a better capital treatment. In particular, the risk weight for senior STS tranches will be subject to a $10 \%$ floor, while non-senior tranches will receive a $15 \%$ floor (BCBS, 2016). ${ }^{72}$ While the STS criteria impose the origination of homogeneous pools of assets, this does not extend to the risk profile of the assets in the pool, which may well vary. As stated earlier in the context of the LR, the relative risk insensitivity of the new Basel approach means that despite asset homogeneity, large banks may still be able to securitise under the STS label pools of high-risk assets. Ultimately it is legitimate to argue that the revised securitisation framework under Basel III, and the contextual application of the STS framework, may represent a regulatory arbitrage opportunity for the large dealer banks (in this sense see also Cullen, 2018). Despite the overall counter-cyclical thrust of the Basel III framework (BCBS, 2011), the preferential capital requirements under the STS have the potential to incentivise securitisation beyond a desirable level, in light of the dynamics of the leverage cycle illustrated in part D of this article. 


\section{Conclusion}

This article proposes a different perspective on the EU plan aimed at further integrating European capital markets through the CMU. At the heart of this critique is the realisation that through the CMU the Commission is seeking to resuscitate a number of practices and credit channels that were prevalent in the pre-crisis years. In particular, a careful reading of the Commission Green Paper shows that market-based finance, and in particular securitisation, are central to the envisaged functioning of EU capital markets. This is also confirmed by the implementation stage of different segments of the CMU, where a Regulation on STS Securitisation has been adopted in 2017, while other channels of finance, such as equity crowdfunding for instance, have not been pursued with the same eagerness (EU Commission Press Release). Overall, as was discussed earlier in Section 3, the real economy and SME tags that have been (self)attributed to this project are to a large degree a means to make it more appealing to a diverse range of stakeholders.

Section 3 of this article explained that, notwithstanding its claims, the CMU is very likely to lead to more financialised economies, to increased debt in the financial system and inevitably to higher levels of leverage. Moreover, the push to revive both securitisation and the repo market - bearing in mind that both have remained stagnant after the GFC - shows that there is a real possibility to see a new emergence of the securitised banking model, the risks of which are explained in part D. Despite the introduction under the new Basel III framework (BCBS, 2014) of a set of standards aimed at reducing leverage in the financial system, there are legitimate concerns that these alone will not be sufficient to significantly reduce risk and instability.

Concerns about the viability of the post-crisis financial architecture, expounded in part E of this article, bring the discussion back to some of the criticism made by Lord Turner. He questioned the state of the financial system, particularly its debt creation effect and the belief that market discipline would suffice in ensuring adequate control systems and the reining in of excessive risks (Turner, 2016). As was discussed throughout this article, policies directed at increasing private sector debt and leverage seem to remain undisputed. Turner reflects in his work on the inevitability of this pattern of credit intensive growth, which, he argues, does not support productive capital investments (Turner, 2016). This conclusion is shared in some way by Geanakoplos who refers in his work to eight reasons why the leverage cycle is bad for the real economy. These relate to three main areas of concern, namely the large debt and the ensuing bankruptcies in the leverage cycle; the swings in asset prices that characterise the leverage cycle (leading to bubbles and bursts); and the inefficient government intervention that normally follows a cycle (Geanakoplos, 2014, p. 320). Along similar lines, in their work on the "finance franchise", Hockett and Omarova (2017) identified the franchisor absenteeism (the state ceding the management of financial resources to private financial institutions) as a key regulatory problem, leading to a flawed modulation of credit. They called for a more central role of the franchisor.

These reflections should provide some context to the critique of the CMU institutional structure, expounded in part E. There is in other words a shared concern that for integrated European capital markets to deliver their announced economic and social goals, a strong institutional structure, centred on a strong supervisor, needs to be a precondition. ${ }^{73}$ Currently, this is lacking.

In a recent speech on sustainable finance at the EU Parliament, vice-president Dombrovskis highlighted the commitment to focus on long-term goals and in the interest of the real economy. He emphasised the importance of embedding sustainable goals into financial regulation and stressed that efficient capital markets can contribute to sustainable societies (EU Parliament, 2017). His caveat however is quite substantial. Dombrovskis pointed out that a financial stability dimension is needed so that capital markets can adequately internalise risks and make the financial system more resilient. For this to happen, a deeper re-engineering of the financial system is necessary (EU Parliament, 2017). In light of the critique put forward in Section 4 and 5, this article contends that while a number of safeguards to financial stability have been introduced, these do not amount to the re-engineering of the financial system that would ensure long-term, resilient and sustainable financial markets.

\section{Acknowledgements}

I thank the Convivium reviewers for very useful comments. Errors remain my own.

\section{Notes}

1 Aristotele "Politics I", Chapter 10, 1258a35, originally published between 335-323 BC, OUP 1995.

2 In a nutshell, the CMU can be defined as the plan that the EU Commission has devised to fully implement the integration of member states' capital markets. Through this initiative the Commission aims to create a true single market for capital. The CMU was initiated with 
a Green Paper published by the Commission in February 2015 (COM(2015) 63 final), followed by an accompanying document (SWD(2015) 13) and then by an Action Plan published in September 2015 (SWD(2015) 183 final). After the initial consultation process, in June 2017 the Commission updated the Action Plan with the Mid-term review of the CMU action plan (COM(2017) 292 final). While a number of legislative processes have already been initiated - as discussed in this article the STS Regulation came into force earlier in 2018 (EU Regulation 2017/2402) - in May 2018 the Commission presented further legislative proposals on sustainable finance. According to the action plan, by 2019 the building blocks of an integrated EU capital market will be established.

3 In the US this occurred through the enactment of the Commodities Futures Modernization Act 2000, that liberalised common law distinctions between commercial and speculative derivatives; in the UK, the Financial Services Act 1986 abolished old prohibitions of the Gaming Act 1845, thereby facilitating market practices related to speculative derivatives; At EU level, the European Second Banking Coordination Directive (Directive 89/646/EEC, replaced by Directive 2006/48/EC) enabled European banks to engage in investment-type activities that were not traditionally allowed in deposit-taking institutions.

4 The repeal of the Glass Steagall Act of 1933, through the Gramm-Leach-Bliley Act 1999, provided the final regulatory (or perhaps deregulatory) justification for abandoning the separation between commercial and investment banking activities. While this formalised the legality of mergers between commercial banks and investment firms (a prominent one having taken place in 1998 when Citicorp merged with Travelers Groups, which had in 1995 taken over Salomon Brothers, a major bond dealer). The repeal of the final prohibitions left of the Glass Steagall Act allowed the formation of huge financial conglomerates, and enabled them to compete for the more profitable investment business while enjoying implicit government guarantee. It is worth stressing that the process that saw banks in the US expanding their range of activities started well before the repeal of the Glass Steagall Act in 1999, and it can be traced back to the early 1980s (Cetorelli, 2017). In the UK similarly, in the context of the 1986 'big-bang' in financial regulation, differences between commercial banks and merchant banks were obliterated, and membership to the Stock Exchange was opened to corporate members.

5 While this process is sometimes associated with deregulation, it often was accompanied by a re-regulation of the financial services industry, which was designed to achieve market-oriented forms of regulation and outcomes. See on this (Cerny, 1993)

6 In the US private sector debt grew from $53 \%$ in 1950 to $170 \%$ of GDP in 2007.

7 Turner argues that this is contrary to conventional belief grounded on the benefits of having deep financial markets, whereby financial innovation was seen as having a role for completing markets and in turn market discipline orthodoxy would allow reining in resulting complexity (see pp. 61-62).

8 Turner notes that $65 \%$ of bank lending is directed at residential mortgages, $14 \%$ at commercial real estate, $14 \%$ at non-real estate business, $7 \%$ to consumer credit. As much of the lending was originated against already existing assets - chiefly real estate ones - Turner contended that the credit growth during the above period did not contribute substantially to new capital investments.

9 Even though more traditional literature presents a clear dichotomy between bank finance and capital markets finance, more recent findings suggest that there is complementarity of products and services that they offer. This is partly due to the changes in banks over the last decades, whereby they progressively moved from a relationship-based business model, towards a transaction-based business model. This shift strongly accentuated the links between banks and capital markets. See Commission Accompanying Document 2015, p. 23. On the integration of banking and capital markets, see also Hockett and Omarova (2017), part V.

10 But also in France for instance, where the market capitalisation of stock and private bonds (as a percentage of GDP) is higher than the level of bank credit to the private sector. See The Economist (2014).

11 Despite the steady growth of capital markets activities in a number of EU countries, and notwithstanding the broader meaning of capital markets activities (often involving banks), recent data suggests that there remains a fundamental difference in the amount of bank assets vis-à-vis capital markets assets as a percentage of GDP in different jurisdictions. A comparison between the US and the EU is conclusive. See EU Commission, 2015b)a, p. 11.

12 Kaserer and Rapp found a positive impact of the increased size of capital markets on economic growth and they stress that equity markets in particular can provide the ideal platforms to access finance for long-term risky investments.

13 Think as an example about a 25-year mortgage on the one side of the balance sheet and short-term repo funding on the other, which needs to be rolled over on a daily basis.

14 It needs to be said though that after 2011 Europe was invested by the global crisis through the sovereign debt crisis and that responses were weaker than those in the UK and US with respect to public finances.

15 It has been traditionally the case for capital markets, especially in Europe, to be the playground for large "blue chip" corporations. SMEs on the other hand traditionally do not match the business model and the corporate governance patterns that are required to participate in capital markets.

16 One possible way in which SMEs could benefit from the CMU is through the securitisation of SME loans. While this may not be economically viable at the individual small bank's level, due to the costs associated with securitisation and the relative small size of the portfolios, loans extended to SMEs through Peer-to-Peer platforms have started to be securitised in the UK in the last two years. The possibility to tap wholesale markets would therefore enable banks and/or other intermediaries to provide finance to SMEs more consistently.

17 While shadow banks cannot create and hold deposits, they create money-like claims.

18 Importantly, Ricks explains how deposit-taking institutions issue money claims, thus expanding the monetary base. It is also stressed in his article how other types of money claims, such as repo or money market claims, also represent forms of fractional reserve banking and as a result incur the same type of risks related to maturity transformation.

19 It needs to be remembered though that post-2008 there has been a profound rethinking of financial regulation along the systemic dimension of the financial system. This led to an increased focus on macro-prudential policies and regulatory tools which, among other things, are directed at curbing credit creation. Five relevant macro-prudential policies in this sense are: limits on loan-to-value ratios; capital requirements; liquidity covered ratios; dynamic loan-loss provisions; margin requirements on repos. Some of these measures are discussed in part E of this article. For a critique, see Goodhart el al. (2013) and Cranston et al. (2017).

20 While capital requirements were traditionally designed to control and prevent excesses in private credit creation, the development of the shadow banking system, coupled with a flawed regulatory framework of capital requirements under Basel I and II, allowed the uncontrolled expansion of leverage in the shadow banking system. See for an explanation Blair (2013) pp. 422-424; Blair (2010) p. 251.

21 As it transpires from the previously cited Bank of England paper on money creation, legal reserve requirements are not really in place in the UK and some commentators argue that even when in place they do not really limit the power of banks to create money.

22 According to the Bank of England, European Central Bank (2014), it is not reserve requirements that limit the amount of money that private banks can create, but rather central banks' monetary policies, chiefly through the setting of interest rates. The whole idea of fractional reserve banking is further demystified by Hockett and Omarova in their 2017 article. Relevant perspectives on money creation are also provided by Moe (2018) and Biondi (2018) and generally in the AEL 2018 Symposium on "The Money Problem: Perspectives on Money, Banking and Financial Regulation".

23 Ricks explains that, like deposits, repo transactions create money claims, but unlike deposits they are not covered by deposit insurance protection, lender of last resort protection, and limitation of risk accumulation through capital requirements. 
24 Biondi and Zhou observe that interbank lending, whereby financial institutions settle and refinance their positions, also involves a process of money creation at the aggregate level.

25 Another factor that contributed to increases in leverage is the moral hazard that allowed large banks to operate under implicit government guarantee. This was discussed in Section 2.

26 This study in particular shows that while there was no visible increase in leverage for commercial banks, from the early 2000 s there was a visible increase in leverage for investment banks worldwide and large commercial banks in the US.

27 In pre-crisis years it was widely believed that in efficient and unregulated capital markets financial institutions would not extend excessive amounts of credit, due to the self-correcting forces of the market. For an explanation see Blair (2013), p. 422.

28 These refer to promises accepted by banks to be paid in the future.

29 Pozsar explains in his seminal work that credit intermediation in dealer banks entailed a number of processes and that each of those processes involved a certain type of shadow bank entity. These processes would include for instance loan origination, asset-backed securities issuance, asset-backed securities warehousing, wholesale funding, and so on.

30 These refer to promises to pay issued by the bank.

31 It is worth noting that these ratings proved to be inaccurate and grounded on flawed methodologies. For studies on this, see (Johnston, 2011; Partnoy, 2009).

32 The slicing and repackaging of assets into AAA tranches was partly driven by the strong demand for highly rated securities to be used as collateral in repo transactions.

33 As an example, the haircut is calculated on the value of the collateral, so a $10 \%$ haircut on collateral worth $£ 110$ would give a loan of $£ 99$.

34 Another factor that led to the growth of the repo market was the cap introduced in the banking sector to deposit insurance schemes.

35 The importance of the repo market in the context of securitised banking can be represented by the comparison between total assets in the traditional banking system and the total assets in dealer banks, with the latter relying much more heavily on repo than the former (Gorton \& Metrick, 2012, p. 438).

36 Specifically, what they refer to as public accommodation and monetisation that underscore the creation of credit-money.

37 Effectively this reflects the power of entities in the shadow banking system to create credit in the same fashion as banks do.

38 Hockett and Omarova (2017), p. 1195 stress that this integration allowed non-bank institutions to access banks' deposit base, which effectively allowed directing public resources into the shadow banking system. Again this contributed to the further amplification and replication of banks' credit creation among non-bank entities.

39 Dysfunctional because the flow of credit created was primarily being re-directed towards the financial system rather than the real economy.

40 Discussing among other things whether reforms in the areas of capital requirements, leverage ratio and liquidity are likely to address this failure.

41 It could be argued that problems of trust in the global financial system arose in the summer of 2007 when interbank markets started to slow down, only to recover following central bank intervention.

42 This is primarily the case in the US where a pro-business agenda is lifting optimism among investors and is creating opportunities for financial institutions; in other words an example of how the memory of the crisis fades away together with cautious risk-taking. See (Abrego, 2017; Verhage, 2017).

43 Geanakoplos clarifies that the equilibrium of supply and demand influences both interest rates and collateral rates. More specifically, the interest rate reflects borrowers' impatience, while the collateral rate reflects the volatility of asset prices and therefore lenders' uncertainty. 44 As explained later in this section, in the pre-crisis years margins in the repo market declined to $10 \%$ and below, because the assets pledged as collateral were considered very safe. The perception of safety was again driven by market forces, namely market participants' optimism, flawed ratings and opaque and unregulated transactional structures.

45 This refers to the financial losses suffered by a bank as a consequence of defaults incurred by borrowers on loans originated by the bank. 46 This is a consequence of the collapse in market value of the underlying assets, and in theory margins can increase indefinitely.

47 Geanakoplos (2010b), p. 112 notes that in fact banks could borrow as much as 98.4 cents on the dollar on AAA assets, which were only supposed (according to credit rating agencies' valuations) to have a risk of default over a ten years period of 1 in 100.

48 Geanakoplos observes that a bank securitising a pool of mortgages could borrow $70 \%$ of the collective value of the pool, while it would be very difficult to borrow anything against the underlying loans in the securitised pool.

49 The FIH in essence theorised the impact of debt on the behaviour of the financial system and also the way in which debt is validated in the system.

50 The Securitisation Regulation in the context of the CMU in particular can be seen as an enabling regulation that may allow large banks to restart pre-crisis speculative practices.

51 It was explained earlier in this article that leverage increases profitability, and in particular return on equity, for the individual firm and it is therefore rational for shareholders and management to implement strategies that are aimed at leveraged-based asset growth. In financial markets where resources are finite, and where trades are characterised as zero-sum-games, this leads to a tragedy of commons where individual actors' self-interest is contrary to the welfare of the system as a whole (the common good of all market participants). The tragedy of commons was first theorised by G. Hardin.

52 While there is no accepted definition of sustainable securitisation, an idea of high-quality securitisation was widely discussed at the earlier stages of the consultation process. This idea was grounded on simpler transactional structures with transparent underlying assets and predictability of risks and performance for investors. These qualities, that have eventually to some extent flowed into the STS framework, were thought to contribute to a sustainable securitisation market (BoE, ECB, 2014). The STS Regulation refers, among its aims, to "a sustainable securitisation market that will improve the financing of the EU economy, while ensuring financial stability and investor protection".

53 This, among other things, is achieved under Article 6 of the Regulation, through the $5 \%$ risk retention requirement.

54 This is more specifically prohibited in Article 8 of the Regulation where it is stated that the underlying exposures in a securitisation cannot be securitisation positions.

55 This means that Article 21 of the Regulation specifies that while interest rate and currency risks should be mitigated through specific derivatives, outside these hedging purposes, the SPV should not enter into derivative contracts and should ensure that the asset pool does not include derivatives.

56 Article 22 of the Regulation makes specific reference to the originator/sponsor of the securitisation to make available to investors data on static and dynamic historical default and loss performance for at least five years, as well as the liability cash flow model which precisely represents the contractual relationship between the underlying exposures and the payments flowing between the originator, sponsor, investors, other third parties and the SPV.

57 Article 20 of the Regulation specifies that the assets have to be acquired by the SPV as a result of a true sale. 
58 Synthetic securitisation refers to the practice whereby assets are not sold to the SPV. Instead the risk transfer is achieved through a credit default swap between the originator and the SPV. In the years leading up to the 2008 crisis, synthetics had become the prevailing form of securitisation because they facilitated the process of manufacturing securities that were perceived safe and thus would be considered highly liquid collateral (the top tranches of CDOs for instance). This practice has also been identified as what led to huge increase of leverage as well as the general opacity of the market-based system (see Bavoso, 2013).

59 Article 10 of the Regulation provides for a securitisation repository to be registered with ESMA and to be applicable throughout the Union. While articles 11 and 12 provide details of how ESMA deals with competent national authorities on matters related to the registration of repositories, article 18 clearly states that it is up to the transaction's parties (originator, sponsor or SPV) to notify ESMA that the securitisation meets the requirements of simplicity, transparency and standardisation. This is reiterated in article 27, where it is explained that the notification to ESMA should include details of how the transaction meets the STS requirements, and that the originator or sponsor should liaise with the competent national authority. Article 28 further clarifies that the verification of compliance with the STS criteria is delegated by the competent national authority to a third party, independent entity. Article 29, dealing specifically with supervision, states clearly that competent national authorities are designated to supervise this Regulation.

60 ESMA was created with Regulation (EU) 1095/2010 as a supervisory authority for financial markets.

61 Schwarcz in particular observes that the STS reflects the basic functions of securitisations, as it worked in the 1990s, and thus puts forward a more optimistic view of the Regulation than it is conveyed in this article.

62 This includes typical functions of credit risk management and the ensuing regulatory capital relief that synthetic transactions bring. These structures are said to be mostly originator driven.

63 This involves the aim of the originator to profit from the arbitrage between the higher spread from an underlying low-quality asset, and the lower spread paid on the resulting structure and credit enhanced notes. Unlike balance sheet synthetics, arbitrage synthetics are usually driven by investors' needs and preferences.

64 With the exception of credit rating agencies and trade repositories, where ESMA exerts direct supervisory tasks.

65 In particular, the work of Hockett and Omarova (2017) advocating the regulator's renewed leadership in steering capital markets; and Geanakoplos (2010b) pointing at situations where the role of a public regulator becomes necessary and determinant in averting crises. 66 This assertion is cognisant of the known dangers of regulatory capture (see Stigler, 1971). Namely, the political power exerted by the financial industry risks compromising the regulatory and supervisory goals of the public regulator. And that is precisely why, as it is argued above, it is important to design an authority with adequate institutional powers, and not reliant on market mechanisms, especially for the purpose of ensuring financial stability.

67 Where a repo counterparty resorts to rehypothecation to circumvent a haircut, by borrowing securities against other securities that attract higher haircut as collateral.

68 It needs to be noted that higher levels of capital are accompanied under Basel III by a number of regulatory changes in capital composition, by a stricter definition of common equity, and importantly by increase in capital requirements for trading activities, counterparty credit risk, and capital markets related activities which will trigger higher capital charge. See BCBS (2011), para 9-10.

69 These require tier-1 capital to be dominated by common equity and retained earnings in order to enhance the loss-absorbing capacity of banks' capital base. Common equity must thus amount to at least $4.5 \%$ of risk-weighted assets (RWA), while tier- 1 capital as a whole should amount to at least $6 \%$ of RWA. Tier-2 capital includes instruments issued by consolidated subsidiaries, other instruments not included in tier- 1 and some loan-loss provisions. Tier- 1 and tier-2 capital should amount to at least $8 \%$ of RWA. See BCBS (2011), para 50-57.

70 National authorities have the power to subject individual banks to a countercyclical buffer between 0 and $2.5 \%$ tier- 1 of RWA; banks that are active across jurisdictions would face of course more complex calculations. See (BCBS, 2011) para 58. At the international level, the FSB introduced a systemic risk buffer for banks that are identified as systemically important globally. Under the rule introduced by the FSB globally systemic banks are charged between 1.0 to $4.5 \%$ of each bank's total RWA. See Cranston et al. (2017), pp. 48-49.

71 It refers to the ration between a bank's non-risk weighted assets and its tier- 1 capital; in essence it is designed to supplement the risk weighted capital ratio. As a result, any bank with an unweighted leverage ratio of less than $3 \%$ would be considered undercapitalised (BCBS, 2011, para 12).

72 The risk weight will also depend on the maturity of the securitised bond and on the rating it receives. Under the Basel III framework the hierarchy of approaches to rate securitisation exposures follows: (1) Internal Rating-Based Approach, (2) External Rating-Based Approach, (3) Standardised Approach. As an illustration of the preferential capital treatment of STS securitisation, under the external rating approach, triple-A non-STS senior tranche securitisation would be subject to a risk weight of $15 \%$ for a 1-year maturity, $20 \%$ for a 5-year maturity, whereas triple-A non-senior tranches would be subject to a risk weight of $15 \%$ for a 1-year maturity and $70 \%$ for a 5 -year maturity. For the same rating and maturities, STS securitisation would be subject to risk weights of respectively, $10 \%, 10 \%, 15 \%, 40 \%$.

73 Bearing in mind the caveat explained in footnote 70.

\section{References}

Abbassi, P., lyer, R., Peydro, J., \& Tous, F. (2016). Banks that trade securities grant fewer loans Research Brief, Deutsche Bundesbank Eurosystem.

Abrego, M. (2017). Investor optimism at its highest since 2008 crisis, UBS survey says, Citywire, 20 January. Retrieved December 11, 2017 from https://citywireamericas.com/news/investor-optimism-at-its-highest-since-2008-crisis-ubs-survey-says/a986211

Acharya, V., \& Thakor, A. (2016). The dark side of liquidity creation: Leverage and systemic risk. Journal of Financial Intermediation, 28, 4-21.

Anderson, N., Brooke, M., Hume, M., \& Kurtosiova, M. (2015). A European capital markets union: Implications for growth and stability. Bank of England Financial Stability Paper $n .33$.

Avgouleas, E. (2010). The reform of too-big-to-fail banks: A new regulatory model for the institutional separation of "casino" from "utility" Banking. Retrieved February 14 from SSRN:https://ssrn.com/abstract=1552970

Avgouleas, E. (2012). The Covernance of global financial markets: The law, the economics, the politics. Cambridge: Cambridge University Press.

Avgouleas, E. (2016). Large systemic banks and fractional reserve banking, intractable dilemmas in search of effective solutions. In Arner, D., \& E. Avgouleas (Eds.), Ross Buckley Reconceptualizing Clobal Finance and its Regulation (pp. 659-692). Cambridge: Cambridge University Press.

Avgouleas, E., \& Cullen, J. (2015). Excessive leverage and bankers' pay: Covernance and financial stability costs of a symbiotic relationship. Columbia Journal of European Law, 21. 
Bank of England, European Central Bank. (2014). The case for a better functioning securitisation market in the European union discussion paper.

Bank of International Settlements. (1999). Market liquidity: Research funding and selected implications. Committee on the global financial system, Paper No. 11.

Bank of International Settlements. (2013). Asset encumbrance, financial reform and the demand for collateral assets. Committee on the global financial system, Paper No. 49.

Barth, J. (1991). The great savings and loan debacle. Washington D.C: American Enterprise Institute.

Basel Committee on Banking Supervision. (2013). Basel III: The liquidity coverage ratio and liquidity risk monitoring tools BIS.

Basel Committee on Banking Supervision. (2014). Basel III: The net stable funding ratio. BIS.

Bavoso, V. (2013). Financial innovation and structured finance: The case of securitisation. Company Lawyer, 34(1), 3-11.

Bavoso, V. (2016a). Financial Innovation, derivatives and the UK and US interest rate swap scandals: Drawing new boundaries for the regulation of financial innovation. Clobal Policy, 7(2), 227-236.

Bavoso, V. (2016b). High quality securitisation and EU capital markets union - Is it possible? Accounting, Economics, and Law: A Convivium, 7(3).

Bavoso, V. (2017). Filling the accountability gap in structured finance transactions: The case for a broader fiduciary obligation. Columbia Journal of European Law, 23(2), 369-400.

BCBS. (2011). Basel III: A global regulatory framework for more resilient banks and banking systems.

BCBS. (2014). Basel III leverage ratio framework and disclosure requirementsBIS.

BCBS. (2016). Revisions to the Securitisation Framework.

Bhattacharya, S., Goodhart, C., Tsomocos, D., \& Vardoulakis, A. (2011, September). Minsky's financial instability hypothesis and the leverage cycle. London School of Economics FMC Special Paper.

Biondi, Y. (2011). Disagreement-based trading and speculation: Implications for financial regulation and economic theory. Accounting Economics and Law, (1), 1-6.

Biondi, Y. (2013). Hyman Minsky's financial instability hypothesis and the accounting structure of the economy. Accounting Economics and Law, Convivium, 3s(3), 141-166.

Biondi, Y. (2016). Empowering market-based finance: A note on bank bail-outs in the aftermath of the north Atlantic financial crisis of 2007. Accounting Economics and Law, 6(1), 79-84.

Biondi, Y. (2018). Banking, money and credit: A systemic perspective. Accounting Economics and Law, 8(2), 1-40.

Biondi, Y., \& Graeff, I. (2017). Rethinking bank shareholder equity: The case of Deutsche bank. Accounting Forum (2017). doi:10.1016/j.accfor.2017.06.003

Biondi, Y., \& Zhou, F. (2017). Interbank credit and the money manufacturing process. A systemic perspective on financial stability. Bank of England conference in honour of Oswald Distinguished Professor William A. Barnett. Bank of England, London. Retrieved May 23-24, 2017 from SSRN: https://ssrn.com/abstract=2924402

Blair, M. (2010). Financial innovation, leverage, bubbles and the distribution of income. Review of Banking \& Financial Law, $30,225$.

Blair, M. (2013). Making money: Leverage and private sector money creation. Seattle University Law Review, 36, 417-454.

Blundell-Wignall, A. (2011). Solving the financial and sovereign debt crisis in Europe. OECD Journal: Financial Market Trends, 2011 (2), 1-23.

Bookstaber, R. (2007). A Demon of our own design: Markets, hedge funds and the perils offinancial innovation. Oxford: Wiley.

Cecchetti, S., \& Kharroubi, E. (2015).Why does financial sector growth crowd out real economic growth? BIS Working Paper no.490.

Cerny, P. (1993). The deregulation and re-regulation of financial markets in a more open world. In Finance and world politics: Markets, regimes and states in the post-hegemonic era (pp. 51-85). Cheltenham: Edward Elgar.

Cetorelli, N. (2014). Hybrid Intermediaries. Staffreport 705. Federal Reserve Bank of New York.

Cetorelli, N. (2017). Were banks ‘Boring' before the repeal of glass-steagall? Liberty Street Economics. Retireved July 31, 2017 from http://libertystreeteconomics.newyorkfed.org/2017/07/were-banks-boring-before-the-repeal-of-glass-steagall.html

Coffee, J. (2009). What went wrong? An initial enquiry into the causes of the 2008 financial crisis. Journal of Corporate Law Studies, 9, 41.

Constancio, V. (2016). Challenges for the European banking industry. Lecture at the conference on 'European Banking industry: what's next?' University of Navarra, Madrid, 7, July.

Copeland, A., Martin, A., \& Walker, M. (2011). Repo runs: Evidence from the Tri-Party repo market. StaffReport No. 506. Federal Reserve Bank of New York, July.

Cranston, R., Avgouleas, E., Van Zwieten, K., Hare, C., \& Van Sante, T. (2017). Principles of banking law. Oxford: Oxford University Press.

Cullen, J. (2014). Executive compensation in imperfect financial markets. Cheltenham: Edward Elgar.

Cullen, J. (2017a). Liquidity, securitisation and mortgage markets: A legal and minskyan analysis. Draft Spring.

Cullen, J. (2017b). The repo market: Collateral and systemic risk. In Chiu, \& MacNeil (Eds.), Research handbook on shadow banking. Cheltenham: Edward Elgar.

Cullen, J. (2018). Securitisation, ring-fencing and housing bubbles: Financial stability implications of UK and EU bank reforms. Journal of Financial Regulation, 4(1), 73-118.

Deutsche Bundesbank Eurosystem. (2017). Time series BBK01.PQ1601: Lending to domestic enterprises and self-employed persons/Total/Credit cooperatives. Retireved June 19, 2017 from https://www.bundesbank.de/Navigation/EN/Statistics/Time_series_databases/Banks_ and_other_financial_institutions/banks_and_other_financial_institutions_details_value_node.html?tsld=BBK01.PQ1601\&listld=www_ s104_vjkre_15

The Economist. (2014, October 27). Stress Test Results Will Not Turn the Euro Zone Around.

Eichengreen, B. (2008). Globalizing capital: A history of the international monetary system. Princeton: Princeton University Press.

Elliott, D. (2015, February). Capital markets Union in Europe: Initial impressions. Brookings. Retrieved from https://www.brookings.edu/research/capital-markets-union-in-europe-initial-impressions/

Epstein, G. (2005). Financialization and the world economy. Cheltenham: Edward Elgar.

EU Commission. (2015a). Commission staff working document - economic analysis accompanying the action plan on building a capital markets union. SWD(2015) 183 Final. 
EU Commission. (2015b). Building a capital markets union - accompanying the Green Paper. COM 2015/63.

EU Commission. (2017). Capital markets union, Mid-term review, Consultation Document.

EU Comission. (2017). The EU reaches agreement on reviving the securitisation market. Retireved June 19, 2017 from https://ec.europa.eu/info/business-economy-euro/growth-and-investment/capital-markets-union/capital-markets-union-actionplan_en

EU Commission Green Paper. (2015). Building a Capital Markets Union. Com(2015) 63 Final.

EU Parliament. (2017). Vice-President's Valdis Dombrovskis speech on sustainable finance at the European parliament. Retireved June 19, 2017 from https://ec.europa.eu/commission/commissioners/2014-2019/dombrovskis/announcements/vice-presidents-valdisdombrovskis-speech-sustainable-finance-european-parliament_en

EU Parliament Briefing. (2016, June). Synthetic securitisation. A closer look.

EU Parliament Briefing. (2018, January). Common rules and new framework for securitisation.

EU Regulation. 2015/2365. On transparency of securities financing transactions and of reuse and amending regulation (EU) No.648/2012.

EU Regulation. 2017/2402. laying down a general framework for securitisation and creating a specific framework for simple, transparent and standardised securitisation.

EU Regulation. (2015). Laying down common rules on securitisation and creating a European framework for Simple, Transparent and Standardised Securitisation, and amending Directive 2009/138/EC, 2011/61/EU, and Regulation (EC) 1060/2009 and 648/2012, COM(2015)472 final.

EU Regulation (2012). Regulation on OTC derivatives, central counterparties and trade repositories (EMIR) Central counterparties and trade repositories, No 648/2012.

European Banking Authority. (2015, December). The EBA report on synthetic securitisation.

Finance Watch. (2014, December). A missed opportunity to revive boring finance.

Financial Conduct Authority. (2016, May). Market-based finance: Its contribution and emerging issues. Occasional Paper 18.

Fostel, A., \& Ceanakoplos, J. (2013). Reviewing the leverage cycle. Cowles foundation discussion paper No 1918,29.

FSB. (2015, November). Transforming shadow banking into resilient market-based finance: Regulatory framework for haircuts on non-centrally cleared securities financing transactions.

G30. (2016, November). Shadow banking and capital markets: Risks and opportunities. Washington.

Gabor, D. (2016). The (impossible) repo trinity: The political economy of repo markets. Review of International Political Economy, 23(6), 9671000.

Gabor, D., \& Ban, C. (2016). Banking on bonds: On the new links between states and markets. Journal of Common Market Studies, 54(3), 617-635.

Gabor, D., \& Vestergaard, J. (2015, April). Capital markets union: The systemic issues buried deep in the market infrastructure plan. FEPS Policy Brief.

Galbraith, J. K. (1994). A short history of financial euphoria. London: Penguin.

Gallino, L. (2011). Finanzcapitalismo - La Civilta' del Denaro in Crisi. Torino: Einaudi.

Ceanakoplos, J. (2010). The leverage cycle. In Acemoglu, D., K. Rogoff, \& M. Woodford (Eds.), NBER macroeconomics annual 2009 (Vol. 24, pp. 1-65)

Geanakoplos, J. (2010b, August). Solving the present crisis and managing the leverage cycle. Economic Policy Review. Federal Reserve Bank of New York.

Geanakoplos, J. (2014). Leverage, default and forgiveness: Lessons from American and European crises. Journal of Macroeconomics, 39, 313-333.

Ceanakoplos, J., \& Zame, W. (2010). Collateralized security markets. Levine Working Paper.

Coodhart, C., Kashyap, A., Tsomocos, D., \& Vardoulakis, A. (2013). An integral framework for analysing multiple financial regulations. International Journal of Central Banking, 9, 109.

Gorton, G. (2007). The Panic of 2007. NBER Working Paper 14358.

Gorton, G. \& Metrick, A. (2012). Securitized Banking and the run on the repo. Journal of Financial Economics, 104, 425-451.

Grill, M., Lang, J., \& Smith, J. (2015). The leverage ratio, risk-taking and Bank stability. Special Feature EBA StaffFinancial Stability Review.

Haldane, A., \& May, R. (2011). Systemic risk in banking ecosystems. Nature, 469, 351-355. January.

Hardin, G. (1968). The tragedy of commons. Science, 162(3852), 1243-1248.

Hasan, I., Jackowicz, K., Kowalewski, O., \& Kozlowski, L. (2014). Bank ownerships structure, SME lending and local credit markets. Bank of Finland Research Discussion Paper 22. Retireved June 19, 2017 from https://ideas.repec.org/p/bof/bofrdp/2014_022.html

Hockett, R., \& Omarova, S. (2017). The finance franchise. Cornell Law Review, 102, 1143.

IMF. (2014). Shadow banking around the globe: How large and how risky? Clobal Financial Stability Report, Chapter 2. International Monetary Fund.

IMF. (2015, May). Rethinking financial deepening: Stability and growth in emerging markets. IMFStaffDiscussion Note.

Johnston, A. (2011). Corporate governance is the problem, not the solution: A critical appraisal of the European regulation on credit rating agencies. Journal of Corporate Law Studies, 11(2), 395-441.

Kalemli-Ozcan, S., Sorensen, B., \& Yesiltas, S. (2011) Leverage across firms, Banks, and Countries. NBER Working Paper No. 17354.

Kaserer, C., \& Rapp, M. (2014, March). Capital markets and economic growth - long-term trends and policy challenges. Research Report. Retireved from http://www.europeanissuers.eu/_lib/newsflash/research_paper_-_release_version_-_march_2014.pdf

Krippner, G. (2005). The financialization of the American economy, Socio-Economic Review, 3, 173-208.

Lannoo, K. (2015). Which union for Europe's capital markets. CEPS/ECMI Policy Brief, No.22/February.

Lewis, M. (2010). The big short. London: Allen Lane.

Loutskina, E. (2011). The Role of securitization in Bank liquidity and funding management. Journal of Financial Economics, 100(663), 663-684.

McLeay, M., Radla, A., \& Thomas, R. (2014). Money creation in the modern economy. London: Bank of England, Quarterly Bulletin.

Mehrling, P., Pozsar, Z., Sweeney, J., \& Neilson, D. (2013). Bagehot was a shadow banker: Shadow banking, central banking and the future of global finance. Retireved from SSRN at http://papers.ssrn.com/sol3/papers.cfm?abstract_id=2232016 
Minsky, H. (1970). Financial instability revisited: The economics of disaster. Prepared for the steering committee for the fundamental reappraisal of the discount mechanism appointed by the board of governors of the federal reserve system.

Minsky, H. (1977). The Financial instability hypothesis: An interpretation of keynes and an alternative to "standard" theory. Challenge, 20(1), 20-27.

Minsky, H. (1980). Capitalist financial processes and the instability of capitalism. Journal of Economic Issues, 14(2), 505-523.

Minsky, H. (1982). Can IT happen again? Essays on instability and finance. Sharper.

Minsky, H. (1992, May). The financial instability hypothesis. Working Paper n.74. The Jerome Levy Economics Institute of Bard College.

Mitchell, L. (2010). Financialism. A (Very) brief history. Creighton Law Review, 43, 323.

Moe, T. (2013). Control of finance as a prerequisite for successful monetary policy: A reinterpretation of henry simons' rules versus Authorities in Monetary Policy. Accounting Economics and Law, 3(3), 261-276.

Moe, T. (2015). Shadow Banking: Policy challenges for Central Banks. The Journal of Financial Perspectives, 3(2), 1-28.

Moe, T. (2018). Financial stability and money creation. Accounting Economics and Law, 8(2), 1-16.

Orhangazi, O. (2007). Financialisation and capital accumulation in the Non-Financial corporate sector: A theoretical and empirical investigation on the US Economy: 1973-2003. Cambridge Journal of Economics, 32(6), 863-886.

Partnoy, F. (2009, April). Rethinking regulation of credit rating agencies: An institutional investor perspective. Council of Institutional Investors.

Positive Money. How banks create money. Retireved June 19, 2017 from http://positivemoney.org/how-money-works/how-banks-createmoney/

Pozsar, Z. (2014, July 2). Shadow banking: The money view. Office of Financial Research, Working Paper14-04.

Pozsar, Z., Adrian, T., Ashcroft, A., \& Boesky, H. (2010). Shadow banking. Staffreports, No.458. Federal Reserve Bank of New York.

Pragmatic Capitalism. (2015). The rise of the bond market and its impact on portfolio allocations. Retireved February 25 from http://www.pragcap.com/the-rise-of-the-bond-market-its-impact-on-portfolio-allocations/

Ricks, M. (2011). Regulating money creation after the crisis. Harvard Business Law Review, 1, 75.

Ricks, M. (2016). The money problem: Rethinking financial regulation. University of Chicago Press.

Sapir, A., Veron, N., \& Wolff, G. (2018, April). Making a reality of Europe's capital markets union. Bruegel Policy Contribution, Issue 7.

Schammo, P. (2011). The European securities and markets authority: Lifting the veil on the allocation of powers. Common Market Law Review, 48(6), 1879-1913.

Schammo, P. (2017). Market building and the capital markets union: Addressing information barriers in the SME funding market. European Company and Financial Law Review, 14(2), 271-313.

Schwarcz, S. (2009). Regulating complexity in financial markets. Washington University Law Review, 87(2), 211-268.

Schwarcz, S. (2016). Securitization and post-crisis financial regulation. Cornell Law Review Online, 101, 115-139.

Segoviano, M., Jones, B., Lindner, P., \& Blankenheim, J. (2015, January). Securitization: The road ahead. IMFStaffDiscussion Note.

Shirrell, D. (1999). Euro bond trading: How liquid can you get? Euromoney. Retrieved from https://www.euromoney.com/article/b132ofrqgwlymh/euro-bond-trading-how-liquid-can-you-get

Simkovic, M. (2009). Secret liens and the financial crisis of 2008. American Bankruptcy Law Journal, 83, 253.

Stigler, G. (1971). The theory of economic regulation. The Bell Journal of Economics and Management Science, 2(1), 3-21.

Stout, L. (2011). Risk, speculation, and OTC derivatives: An inaugural essay for convivium. Accounting Economics and Law, 1(1), 1-13.

Thiemann, M. (2012). Out of the shadows?: Accounting for special purpose entities in European banking systems. Competition and Change, 16(1), 37-55.

Turner, A. (2009). The turner review: A regulatory response to the global banking crisis. London: FSA.

Turner, A. (2016). Between debt and the devil. Princeton: Princeton University Press.

Varoufakis, Y. (2013). The global minotaur: America, Europe and the future of the Global Economy. London: Zed Books.

Verhage, J. (2017, January 18). U.S. investor optimism highest since crisis as trump era dawns. Bloomberg Markets. (last accessed on 11/12/2017).

Von der Becke, S., \& Sornette, D. (2017). An asset-based framework of credit creation (applied to the global financial crisis). Accounting Economics and Law.

Wagner, W. (2011). Systemic liquidation risk and the diversity-diversification trade-off. The Journal of Finance, 6(4), 1141-1175.

Wray, R. (2013). What do Banks do? What should Banks do? A minskyan perspective. Accounting Economics and the Law, 3(3), $277-311$.

Yongoua Tchikanda, T. (2016, June). Systemic risk and individual risk: A trade-off? Working Paper, Economix. 